\title{
A Multi-objective MILP Model Proposed to Optimize a Supply Chain Network for Microalgae-based Biofuels and Co-products: A Case Study in Iran
}

\section{Mohammad Ehsan Zerafati}

University of Tehran College of Engineering

\section{Ali Bozorgi-Amiri}

University of Tehran College of Engineering

Amir-Mohammad Golmohammadi ( $\square$ a-golmohammadi@araku.ac.ir )

Arak University https://orcid.org/0000-0001-5467-9838

\section{Fariborz Jolai}

University of Tehran College of Engineering

\section{Research Article}

Keywords: Biofuel and co-product supply chain, Microalgae, Mathematical mixed integer linear programing, Multi-objective optimization, Analytical hierarchy process (AHP) method

Posted Date: September 7th, 2021

DOl: https://doi.org/10.21203/rs.3.rs-733880/v1

License: (9) This work is licensed under a Creative Commons Attribution 4.0 International License. Read Full License 
1 A multi-objective MILP model proposed to optimize a supply chain network for microalgae-based

2 biofuels and co-products: A case study in Iran

3

4

5

6

7

8

9

Mohammad Ehsan Zerafati ${ }^{11}$, Ali Bozorgi-Amiri ${ }^{2}$ and Amir Mohammad Golmohammadi ${ }^{3}$ and Fariborz Jolai $^{4}$

${ }^{1}$ School of Industrial Engineering, College of Engineering, University of Tehran, North Kargar, Tehran, Iran. P.O.X. 11155-4563

ehsanzerafati@ut.ac.ir

${ }^{2}$ School of Industrial Engineering, College of Engineering, University of Tehran, North Kargar, Tehran, Iran. P.O.X. 11155-4563

alibozorgi@ut.ac.ir

${ }^{3}$ School of Industrial Engineering, College of Engineering, University of Arak, Arak, Iran P.O.X. 3848177584

a-golmohammadi@araku.ac.ir

${ }^{4}$ School of Industrial Engineering, College of Engineering, University of Tehran, Tehran, Iran, fjolai@ut.ac.ir

\begin{abstract}
Recently, due to the efficiency of cultivating microalgae, researchers and investors have paid considerable attention to the production of different biofuel products that are environmentally friendly. In this study, a two-stage deterministic model is proposed to design a microalgae-based biofuels and co-products supply chain network (MBCSCN). In the first stage, the appropriate locations for the cultivation of microalgae are identified through the analytical hierarchy process (AHP). In the second stage, a deterministic mathematical mixed integer linear programing (MILP) model is developed for a period of five years based on the criteria of economic and environmental impacts. The economic objective function maximizes the overall profit, while the environmental impacts objective function seeks to minimize the consumed fossil fuel throughout the supply chain. Then, a multi-objective MILP optimization problem is solved using the $\varepsilon$-constraint method. The proposed model is evaluated through a case study in Iran. It has helped to identify appropriate locations for the cultivation of microalgae and to specify the required quantity of feedstock, the species of microalgae, the required technology, and the transportation modes in each step of the supply chain.
\end{abstract}

Keywords: Biofuel and co-product supply chain, Microalgae, Mathematical mixed integer linear programing, Multi-objective optimization, Analytical hierarchy process (AHP) method

\title{
1. Introduction
}

\footnotetext{
${ }^{1}$ Contact Amir Mohammad Golmohammadi, School of Industrial Engineering, College of Engineering, University
} of Arak, Iran P.O.X. 38481-77584, Tell: +98 86 32620000, E-mail Address: a-golmohammadi@arak.ac.ir 
In recent years, the growth of population and economy has led to the increase of demand for energy. Furthermore, environmental concerns about massive greenhouse gas (GHG) emissions from fossil fuels have made renewable energy resources a key and desired solution to bring security to the supply of sustainable and environmentally-friendly energy (Coleman et al., 2014; Mohtashami, Aghsami, \& Jolai, 2020). Among different renewable energy resources, biofuels have attracted great attention (Fallahpour et al., 2021; Mohtashami, Bozorgi-Amiri, \& Tavakkoli-Moghaddam, 2021). However, their production, which is based on agricultural biomass, faces major sustainability challenges. Cultivating biomass like corn and soybeans on a large scale requires huge amount of fresh water. Since fresh water resources are limited, supplying water for farmers is costly. In addition, biomass cultivation competes with agricultural food production for fresh water, and it requires large areas of fertile land (Adeniyi, Azimov, \& Burluka, 2018; Coleman et al., 2014; Nasr, Niaki, Kashan, \& Seifbarghy, 2021; Rahemi, Torabi, Avami, \& Jolai, 2020).

Some studies have shown microalgae as a beneficial type of biomass owing to several properties. It needs less land for cultivation, can be cultivated in various types of water and is used in industrial and municipal wastewater. Microalgae can also be used to mitigate atmospheric carbon dioxide, which is due to their ability to absorb $\mathrm{CO}_{2}$ emitted from power plants, and transform it into products (Andrade, Telles, \& Castro, 2020). Microalgae are feedstock with a rapid growth rate and have high oil yields for the production of various biofuels. They can be used to produce large amounts of fat that are convertible into biodiesel. There are other biofuels such as bio-ethanol and bio-methane to derive from microalgae. Microalgae form a great source of valuable co-products (Arabi, Yaghoubi, \& Tajik, 2019b). They are mainly used to produce human food supplements, animal feed and natural food colorants. Since they are anti-oxidants, they are also of pharmaceutical applications (Coleman et al., 2014; Efroymson, Jager, Mandal, Parish, \& Mathews, 2020; Ismail, Ismail, \& El-Sheekh, 2020).

In recent years, there has been considerable research about the processes of producing microalgae and their commercial applications. The first step in this regard is to specify the species of microalgae and to determine the location of microalgae cultivation based on multiple criteria (Branyikova, Prochazkova, Potocar, Jezkova, \& Branyik, 2018; Sharma et al., 2015). Generally, microalgae cultivation systems can be classified into two categories including open pond and photo-bioreactor (PBR). Microalgae cultivation in an open pond system is widely practiced due to its relatively cheaper construction, maintenance and operation on a large scale (Bahadar \& Khan, 2013; Chen, Zhao, \& Qi, 2015; Slade \& Bauen, 2013). The technical and economic evaluation of microalgae cultivation and preprocessing as well as the production of biofuels and their co-products is another common issue to consider in the production of biofuel and commercial products derived from microalgae (Kim et al., 2013; Parsaeifar, Bozorgi-Amiri, Naimi-Sadigh, \& Sangari, 2019). Beside the economic issues, some researchers have focused on the network of processing pathways to specify the optimal pathway for the production of biofuels. For example (Rizwan, Lee, \& Gani, 2013) proposed a processing network model to determine the optimal pathway to produce biodiesel based on microalgae. They also analyzed five steps of the process and then solved the problem with the mixed integer linear programing (MILP) model. (Van Boxtel, Perez-Lopez, Breitmayer, \& Slegers, 2015) discussed a process design for algae production and evaluated the result through the Life Cycle Assessment (LCA) approach. Several studies have also been conducted on environmental considerations, especially the mitigation of GHG emission using microalgae (Ghosh \& Bakshi, 2019; Idrees, 2014). In this case, (Gutiérrez-Arriaga, Serna-González, Ponce-Ortega, \& El-Halwagi, 2014) developed a multi-period multiobjective optimization model to maximize the profit and minimize the environmental impacts in a biorefinery supply chain. For this purpose, they used the Eco-indicator99 LCA technique. Also, (Shi, Handler, 
\& Shonnard, 2019) conducted seven gate-to-gate LCAs of novel unit technologies and evaluated 14 scenarios of incorporating different harvesting and extraction technology combinations into a full algae RD life cycle. Similarly, [21] performed a cradle-to-gate LCA for the industrial production of micro-algal biodiesel. They used an autochthonous Chilean Phaeodactylum tricornutum strain, considering $1 \mathrm{MJ}$ of biodiesel as the functional unit.

Strategic planning for a supply chain involves specifying the location of facilities, the number of facilities in each location, the capacity of each facility and the amount of production so as to minimize the total cost of the chain (Akbarian-Saravi, Mobini, \& Rabbani, 2020; Hadian, Chahardoli, Golmohammadi, \& Mostafaeipour, 2020; Li, Xie, Peng, Gao, \& Wan, 2021). The first step in many research projects is to specify the type of biomass (Babazadeh, Razmi, Rabbani, \& Pishvaee, 2015; Shabbir et al., 2021). Other important strategic decisions concerning a biofuel supply chain include determining the location of feedstock (Balaman \& Selim, 2014), determining the location of the preprocessing site and specifying its capacity (Gong \& You, 2015), locating the processing site and specifying its capacity, and determining the warehouse location for the end-products and its capacity (An, Wilhelm, \& Searcy, 2011; L. Zhang, 2013). The other strategic decisions that have been reviewed in the literature include designing biofuel supply chain networks based on the life cycle assessment approach and environmental issues (Akgul, Shah, \& Papageorgiou, 2012; Bai, Ouyang, \& Pang, 2012; Pahlevan, Hosseini, \& Goli, 2021) and specifying transportation modes throughout the networks (Mojtahedi, Fathollahi-Fard, Tavakkoli-Moghaddam, \& Newton, 2021).

Deterministic and stochastic models are the most frequently used ones to solve supply chain problems. Deterministic models are divided into two categories, namely those with single-objective functions and those with multi-objective functions (Hosseinalizadeh, Khamseh, \& Akhlaghi, 2019). The mathematical mixed integer linear programing (MILP) is the most widely used solution to biofuel supply chain management problems with a single-objective function (Ahn, Lee, Lee, \& Han, 2015; Babazadeh, Ghaderi, $\&$ Pishvaee, 2019). Multi-objective optimization models bring together contradictory objectives to optimize them simultaneously, so an optimal decision has to be made between two or more contradictory objectives. Various types of multi-objective optimization problems are associated with the use of many settlement methods such as the global criterion method, the weighted-sum method and the $\varepsilon$-constraint method. The $\varepsilon$-constraint and the weighted sum methods have been commonly used in the literature to solve multiobjective optimization problems (Abraham \& Jain, 2005; Beiki, Seyedhosseini, Mihardjo, \& Seyedaliakbar, 2021; Branke, Deb, Miettinen, \& Slowiński, 2008; Ghaderi, Moini, \& Pishvaee, 2018; Golmohammadi, Honarvar, Hosseini-Nasab, \& Tavakkoli-Moghaddam, 2020). In many similar studies, analytical hierarchy process (AHP) and data envelopment analysis (DEA) have been used in decision-making processes with several competing options and criteria (Salomon, 2018).

This study seeks to study the development of microalgae and the corresponding industries in Iran. High levels of demand for energy and fuel products, environmental concerns, great diversity of microalgae species, abundant sunlight, favorable temperature as well as vast barren areas and inexpensive land for microalgae cultivation are the features which can provide desirable conditions for a lucrative algal industry in Iran (Arabi, Yaghoubi, \& Tajik, 2019a; Mohseni, Pishvaee, \& Sahebi, 2016; Najafi, Ghobadian, \& Yusaf, 2011). Recently, some studies have been conducted on microalgae-based supply chains in the country. For example, (Asadi, Habibi, Nickel, \& Sahebi, 2018) introduces a viable two-objective model to design an algae biofuel production and distribution network with the integrated formulation of location, inventory 
and routing decisions. Also, (Arabi et al., 2019b) has proposed a MILP model to plan and design a microalgae-based bio-butanol supply chain network. The goal of that study is to minimize the fixed cost of constructing the required facilities, transportation costs, and operational costs. A DEA method is used to reduce the complexity of solving the proposed model. In this line, [46] has proposed a multi-period multiobjective MILP model to design a supply chain of bioenergy production from three different types of biomass including microalgae, Jatropha, and agricultural and livestock wastes.

As summarized in Table 1, in this study, in order to have the comprehensive assessment of the production cost, we have developed a microalgae-based biofuel and co-products supply chain network with six steps which includes cultivation, harvesting, preprocessing, biofuel and co-products production, storage and transporting end products to the customer. Although some research has been done on the applications of the species of microalgae in industry, to the best of our knowledge, there is no study which has focused on biofuels and co-products supply chain with respect to the various species of microalgae. As mentioned in table 1, this research has used 3 species of microalgae for the production of biofuel and co-products. Despite the fact that microalgae can be converted into several types of biofuels and co-products, as far as we know, all of the papers have only studied the production of biofuel in the supply chain, but in this paper, we have studied the production of 3 types of biofuels and 5 types of co-products at the same time in the microalgaebase supply chain network. Moreover, in this research we have applied the corresponding technology according to the microalgae type in all 6 steps of the supply chain. Therefore, the possibilities of finding a better solution have prompted us to develop a new and efficient mathematical model.

To fill the research gaps, the present study proposes a two-stage model for the strategic designing of a microalgae-based biofuel and co-product supply chain network (MBCSCN) in Iran. In the first stage, the AHP method is used to identify appropriate locations for the cultivation of microalgae. In the second stage, a multi-stage and multi-objective MILP model is developed for MBCSCN. The model aims to evaluate the breakeven points of the two objective functions, namely a) maximizing the profit and b) minimizing the environmental impacts of fossil fuel consumption. Therefore, the main contributions of this work are as follows:

- Developing a mathematical model with five steps in the microalgae supply chain, including feedstock supply, cultivation, preprocessing, production of the biofuel and its co-products, and storage and delivery of the end-products to the customer

- Designing a model with two objective functions including the maximization of the profit and the minimization of the environmental impacts of fossil fuel consumption

- Considering three species of microalgae

- Considering three types of biofuels and five types of co-products

- Adopting the corresponding technology and procedure according to microalgae type

Table 1. Summary of the literature review 


\begin{tabular}{|c|c|c|c|c|c|c|c|c|c|c|c|c|c|c|c|c|c|c|c|c|c|c|}
\hline \multirow[b]{2}{*}{ Articles } & \multicolumn{7}{|c|}{ Supply chain steps } & \multicolumn{4}{|c|}{$\begin{array}{l}\text { Objective } \\
\text { functions }\end{array}$} & \multirow{2}{*}{\multicolumn{2}{|c|}{\begin{tabular}{|l} 
Algae \\
types \\
included
\end{tabular}}} & \multicolumn{4}{|c|}{$\begin{array}{l}\text { Final biofuel } \\
\text { products }\end{array}$} & \multicolumn{5}{|c|}{ Final co-product } \\
\hline & 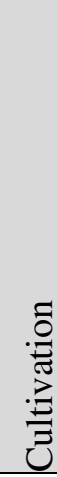 & D & \begin{tabular}{|r} 
\\
.5 \\
0 \\
0 \\
0 \\
0 \\
0
\end{tabular} & 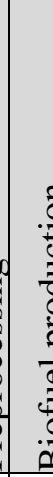 & 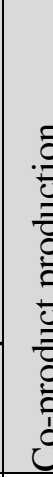 & ( & & & 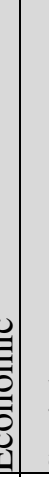 & & 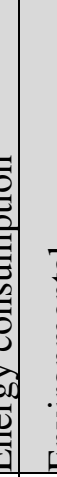 & & & 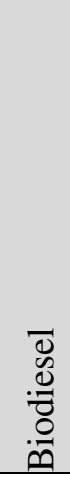 & 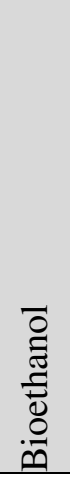 & 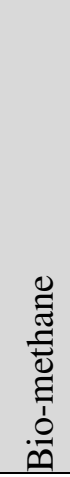 & 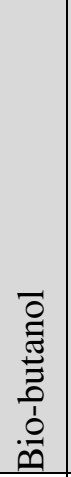 & 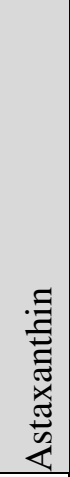 & 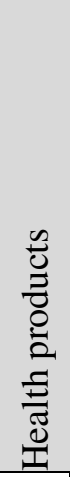 & 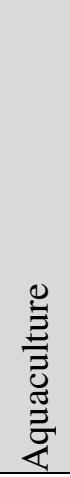 & 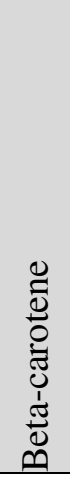 & 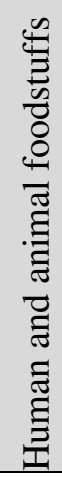 \\
\hline $\begin{array}{l}\text { (Ahn et al., } \\
2015)\end{array}$ & $*$ & & & $*$ & & & & $*$ & & & & & & $*$ & & & & & & & & \\
\hline $\begin{array}{l}\text { (Andrade et al., } \\
2020 \text { ) }\end{array}$ & $*$ & & & * & & & & $*$ & & & & & & $*$ & & & * & & & & & \\
\hline $\begin{array}{l}\text { (Arabi et al., } \\
\text { 2019b) }\end{array}$ & 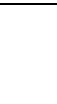 & $*$ & * & $*$ & & & * & $*$ & & & & & & & & & * & & & & & \\
\hline $\begin{array}{l}\text { (Arabi et al., } \\
\text { 2019a) }\end{array}$ & $*$ & $*$ & $*$ & * & & & * & $*$ & & & * & & & $*$ & $*$ & & $*$ & & & & & \\
\hline $\begin{array}{l}\text { (Asadi et al., } \\
\text { 2018) }\end{array}$ & $*$ & $*$ & * & $*$ & & $*$ & & $*$ & & & * & & & & & & & & & & & \\
\hline $\begin{array}{l}\text { (Babazadeh et } \\
\text { al., 2019) }\end{array}$ & * & & $*$ & $*$ & & & & $*$ & & & & & & * & & & & & & & & \\
\hline $\begin{array}{l}\text { (Mohseni et al., } \\
\text { 2016) }\end{array}$ & 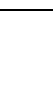 & $*$ & $*$ & $*$ & & & & * & & & & & & * & & & & & & & & \\
\hline $\begin{array}{l}\text { (Mahjoub, } \\
\text { Sahebi, } \\
\text { Mazdeh, \& } \\
\text { Teymouri, } \\
\text { 2020) }\end{array}$ & * & & $*$ & * & & $*$ & & $*$ & & & & & & $*$ & $*$ & & & & & & & * \\
\hline This paper & $*$ & $*$ & * & * & * & $*$ & t; & 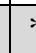 & & * & * & & * & * & $*$ & $*$ & & $*$ & $*$ & * & $*$ & $*$ \\
\hline
\end{tabular}


The rest of this paper is organized in several sections. Section 2 is given to the statement of the problem and the formulation of a mathematical model. Section 3 presents a real case study in Iran, sensitivity analyses and the results. Finally, the paper ends up with the conclusion of the study in section 4 .

\section{Problem statement}

\subsection{Species of microalgae}

This study partly seeks to produce several biofuels and their co-products using different species of microalgae. Microalgae are in various types and can save significant amounts of lipid. The species of microalgae appropriate for this study are those that give higher yields of oil and provide the possibility of producing the intended biofuels and co-products. They should be native to the location of the case study and be compatible with its climatic conditions. Therefore, three species of microalgae including Chlorella vulgaris, Spirulina platensis and Dunaliella salina have been chosen to cultivate (Ismail et al., 2020; Mata, Martins, \& Caetano, 2010).

\subsection{Biofuels}

With regard to the species of microalgae and the employed technology, various biofuels can be produced. Based on the demand in Iran, this study has taken into account three types of biofuels, including biodiesel, bioethanol, and biomethane.

\subsection{Co-products}

Products of different types can be obtained from microalgae (Barry, Wolfe, English, Ruddick, \& Lambert, 2016; K. Zhang, Zhang, \& Wu, 2021). Each one is produced according to the microalgae species and the production technology involved. Therefore, this study focuses on Astaxanthin, health products, aquaculture, and beta-carotene as well as human and animal foodstuffs as co-products.

\subsection{Primary feedstock for microalgae cultivation}

\subsubsection{Water and wastewater treatment system (WWT)}

One of the primary feedstocks required for microalgae cultivation is water, which can be obtained from seas, saline water sources, lakes, or wastewater (WWT) systems (Chu et al., 2021). This research makes use of saline water and WWT to provide the water needed for microalgae cultivation (Fathollahi-Fard, Ahmadi, \& Al-e-Hashem, 2020; Mohseni et al., 2016). The cost of investment in WWT systems is neglected because it is supposed that such systems in Iran have already been constructed.

\subsubsection{CO2 and Carbon Capture System (CCS)}

$\mathrm{CO} 2$ is another resource required for microalgae cultivation. It can be obtained from power plants, factories and petrochemical refineries (Aliyu, Lee, \& Harvey, 2021). However, power plants and other industries should be equipped with a Carbon Capture System (CCS) to absorb the outgoing CO2 (Ahn et al., 2015; Pokoo-Aikins, Nadim, El-Halwagi, \& Mahalec, 2010). The cost of investment in CCSs is ignored because they have already been constructed.

\subsubsection{Nutrients}




\section{Open pond}

Photo bioreactor

Preprocessing

Biofuel production

Production of the coproducts
Procedures

\begin{tabular}{|c|c|c|c|c|}
\hline \multirow[t]{3}{*}{ Preprocessing } & Flocculation and drying & $*$ & $*$ & $*$ \\
\hline & $\begin{array}{l}\text { Sedimentation and } \\
\text { drying }\end{array}$ & $*$ & $*$ & $*$ \\
\hline & Filtration and drying & & & $*$ \\
\hline \multirow[t]{3}{*}{ Biofuel production } & Transesterification & $*$ & $*$ & $*$ \\
\hline & Fermentation & $*$ & $*$ & $*$ \\
\hline & Anaerobic digestion & $*$ & $*$ & $*$ \\
\hline \multirow{2}{*}{$\begin{array}{l}\text { Production of the co- } \\
\text { products }\end{array}$} & Thermal treatment & $*$ & $*$ & $*$ \\
\hline & Anaerobic digestion & $*$ & $*$ & * \\
\hline
\end{tabular}

\section{2.6. Transportation}

202 In this study, the transportation modes within the supply chain network are considered to be train and truck. 203 The truck transportation is possible among all the 35 cities selected for cultivation, and the train 204 transportation is only possible for 15 cities (Babazadeh et al., 2015). These transportation modes are used 205 to transfer the cultivated and preprocessed microalgae to conversion facilities and then to transport the end206 products to the customers. 
This paper discusses the proposed MBCSCN in terms its six layers and double objectives already mentioned in the Introduction section. The MBCSCN is shown in Fig.1. In this network, first, the feedstock including water, $\mathrm{CO} 2$ and nutrients is brought to the microalgae cultivation location, and the intended species of microalgae is cultivated. Then, the cultivated microalgae are preprocessed. This second step involves two operations, including a) harvesting and dewatering and b) drying. Each operation needs a different technology with regard to the species used (Gutiérrez-Arriaga et al., 2014).

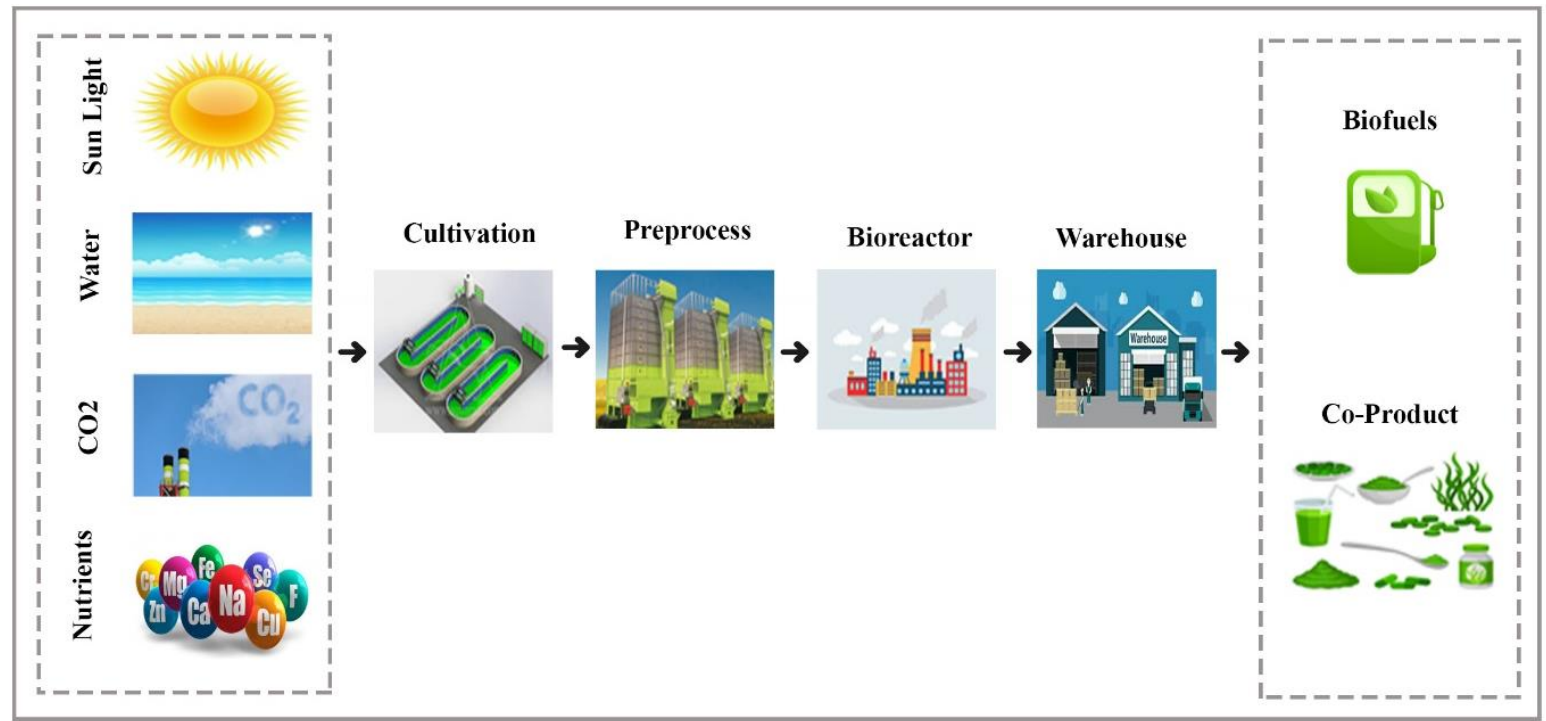

Fig. 1. Structure of the microalgae-based biofuel and co-product supply chain network

After the microalgae are dried, they are taken to the extraction and separation unit. This process is done to reduce the size and the volume of the obtained biomass. It leads to easier transportation, bigger number of delivered shipments, lower transportation costs and lower energy costs. Afterwards, the extracted products are delivered to the warehouses to be prepared for the production step (Davis, Aden, \& Pienkos, 2011).

The next step of the supply chain is the conversion of the preprocessed microalgae to a biofuel and its coproducts. The lipid or other products obtained from the microalgae goes to a biofuel refinery. Then, the end-products are taken to the warehouse and subsequently to the customer (Ismail et al., 2020).

This is how the cultivation location, microalgae species, required technology, production capacity and transportation modes are specified in the MBCSCN. This network ultimately helps to reduce the production costs and fossil fuel consumption.

\subsection{Formulation of the mathematical model}

Briefly speaking, the steps of the microalgae supply chain include microalgae cultivation, preprocessing, production of a biofuel, production of co-products, storage, and delivery to the customer. The sets, indices, parameters and variables are also defined in Tables 3-6 as follows:

Table 3. Sets and indices 


\begin{tabular}{|c|c|}
\hline Sets and indices & Description \\
\hline$G$ & Set of microalgae species ( $g \in G$ ) \\
\hline$F$ & Set of biofuel types ( $f \in F$ ) \\
\hline$P$ & Set of co-product types ( $p \in P$ ) \\
\hline$M$ & Set of markets $(m \in M)$ \\
\hline$U$ & Set of microalgae cultivation methods ( $u \in U$ ) \\
\hline$H$ & Set of microalgae preprocessing methods ( $h \in H$ ) \\
\hline$S$ & Set of microalgae warehouses ( $s \in S$ ) \\
\hline$A$ & Set of biofuel conversions ( $a \in A$ ) \\
\hline$B$ & Set of co-product conversions $(b \in B$ ) \\
\hline$L U$ & Set of microalgae cultivation locations ( $l u \in L U$ ) \\
\hline$L H$ & Set of microalgae preprocess locations ( $l h \in L H$ ) \\
\hline$L S$ & Set of warehouse locations ( $l s \in L S$ ) \\
\hline$L A$ & Set of biofuel conversion facility locations ( $l a \in L A$ ) \\
\hline$L B$ & Set of co-product conversion facility locations ( $l a \in L A$ ) \\
\hline$I$ & Set of feedstock locations $(i \in I$ ) \\
\hline$L$ & Set of feedstock types $(l \in L$ ) \\
\hline$V$ & Set of vehicle modes $(v \in V)$ \\
\hline$T$ & Set of time periods ( $t \in T$ ) \\
\hline
\end{tabular}

\begin{tabular}{|l|l}
\hline Parameters & Description
\end{tabular}




\begin{tabular}{|c|c|}
\hline$f_{l u, u}^{F}$ & $\begin{array}{l}\text { Annualized fixed setup cost of microalgae cultivation facility } l u \text { with } \\
\text { technology } u \text { at time phase }\end{array}$ \\
\hline$f_{l u, u}^{v}$ & $\begin{array}{l}\text { Annualized unit capital for the microalgae cultivation facility at location } l u \\
\text { with technology } u \text { at time phase } t\end{array}$ \\
\hline$f^{\prime} l u, u$ & $\begin{array}{l}\text { Annualize fixed operating cost of microalgae cultivation facility } l u \text {, with } \\
\text { technology } u \text { at time phase }{ }^{t} \text {. }\end{array}$ \\
\hline$L P R l u$ & Land price for microalgae cultivation facility at location $l u$ \\
\hline $\mathrm{Cap}_{u}$ & Maximum allowable capacity with technology $u$ \\
\hline RLcultivation & Required land size for the microalgae cultivation facility \\
\hline$A L S l u$ & Available land size for microalgae cultivation facility $l u$ \\
\hline$f_{l h, h}^{F}$ & $\begin{array}{l}\text { Annualized fixed setup cost of microalgae preprocess facility } l h \text { with } \\
\text { technology } h \text { at time phase }{ }^{t}\end{array}$ \\
\hline$f_{l h, h}^{v}$ & $\begin{array}{l}\text { Annualized unit capital for the microalgae preprocess facility at location } l h \\
\text { with technology } h \text { at time phase }{ }^{t}\end{array}$ \\
\hline fo $l h, h$ & $\begin{array}{l}\text { Annualize fixed operating cost of microalgae preprocess facility } l h \text { with } \\
\text { technology } h \text { at time phase }{ }^{t}\end{array}$ \\
\hline$L P R l h$ & Land price for the microalgae preprocessing facility at location $l h$ \\
\hline $\mathrm{Cap}_{h}$ & Maximum allowable capacity with technology $h$ \\
\hline$R L_{\text {preprocess }}$ & Required land size for the microalgae preprocess facility \\
\hline$A L S l h$ & Available land size for microalgae preprocess facility $l h$ \\
\hline$f_{l s, s}^{F}$ & $\begin{array}{l}\text { Annualized fixed setup cost of warehouse } l s \text { with technology } s \text { at time } \\
\text { phase }{ }^{t}\end{array}$ \\
\hline$f_{l s, s}^{v}$ & $\begin{array}{l}\text { Annualized unit capital for the warehouse at location } l s \text { with technology } \\
s \text { at time phase }{ }^{t}\end{array}$ \\
\hline
\end{tabular}




\begin{tabular}{|c|c|}
\hline$f o_{l s, s}$ & $\begin{array}{l}\text { Annualize fixed operating cost of warehouse } l s \text { with technology } s \text { at time } \\
\text { phase }^{t}\end{array}$ \\
\hline$L P R l s$ & Land price for the warehouse at location $l s$ \\
\hline $\operatorname{Cap}_{S}$ & Maximum allowable capacity with technology $s$ \\
\hline$R L_{\text {storage }}$ & Required land size for the warehouse \\
\hline$A L S l s$ & Available land size for warehouse $l s$ \\
\hline$f_{l a, a}^{F}$ & $\begin{array}{l}\text { Annualized fixed setup cost of bio-refinery facility } l a \text { with technology } a \\
\text { at time phase }{ }^{t}\end{array}$ \\
\hline$f_{l a, a}^{v}$ & $\begin{array}{l}\text { Annualized unit capital for the bio-refinery facility at location } l a \text { with } \\
\text { technology } a \text { at time phase } t\end{array}$ \\
\hline fola,a & $\begin{array}{l}\text { Annualize fixed operating cost of bio-refinery facility } l a \text { with technology } \\
a \text { at time phase }\end{array}$ \\
\hline$L P R l a$ & Land price for the bio-refinery facility at location $l a$ \\
\hline $\operatorname{Cap}_{a}$ & Maximum allowable capacity with technology $a$ \\
\hline RLbiofuel & Required land size for the bio-refinery facility \\
\hline ALSla & Available land size for bio-refinery facility $l a$ \\
\hline$f_{l b, b}^{F}$ & $\begin{array}{l}\text { Annualized fixed setup cost of co-product bio-refinery facility } l b \text { with } \\
\text { technology } b \text { at time phase } t\end{array}$ \\
\hline$f_{l b, b}^{v}$ & $\begin{array}{l}\text { Annualized unit capital for the co-product bio-refinery facility at location } \\
l b \text { with technology } b \text { at time phase } t\end{array}$ \\
\hline$f o l b, b$ & $\begin{array}{l}\text { Annualize fixed operating cost of co-product bio-refinery facility } l b \text { with } \\
\text { technology } b \text { at time phase }{ }^{t}\end{array}$ \\
\hline$L P R l b$ & Land price for the co-product bio-refinery facility at location $l b$ \\
\hline $\mathrm{Cap}_{b}$ & Maximum allowable capacity with technology $b$ \\
\hline
\end{tabular}


$R L_{\text {coproduct }}$

ALS lb

Ctransport $_{v}$

$D_{m, f}^{t}$

$D_{m, p}^{t}$

$D_{I} S_{i, l u}$

DISlu,lh

DIS lh,la

DIS lh,lb

DIS la,ls

$D_{I S} l b, l s$

$D_{I S}{ }_{l s . m}$

$F F g, l u, u$

$F F g, l h, h$

$F F f, l a, a$

$F F_{p, l b, b}$
Required land size for the co-product bio-refinery facility

Available land size for co-product bio-refinery facility $l b$

Cost of transportation (fix \& variable) via mode $v$

Demand for biofuel type $f$ at market $m$ during time phase $t$

Demand for co-product type $p$ at market $m$ during time phase ${ }^{t}$

Distance between location of feedstock $i$ and microalgae cultivation facility $l u$

Distance between microalgae cultivation facility $l u$ and microalgae preprocessing facility $l h$

Distance between microalgae preprocessing facility $l h$ and bio-refinery facility $l a$

Distance between microalgae preprocessing facility $l h$ and co-product biorefinery facility $l b$

Distance between bio-refinery facility $l a$ and warehouse $l s$

Distance between co-product bio-refinery facility $l a$ and warehouse facility $l s$

Distance between warehouse $l s$ and market $m$

Fossil fuel (FF) inputs for producing microalgae species $g$ at microalgae cultivation facility $l u$ with technology $u$ (MJ/ton-1)

FF inputs for harvesting and drying microalgae species $g$ at microalgae preprocessing facility $l h$ with technology $h\left(\mathrm{MJ}_{\text {/ton }}{ }^{-1}\right)$

FF inputs for producing biofuel type $f$ at bio-refinery facility $l a$ with technology $a\left(\mathrm{MJ} / \mathrm{ton}^{-1}\right)$

FF inputs for producing co-product type $p$ at co-product bio-refinery facility $l b$ with technology $b\left(\mathrm{MJ} /\right.$ ton $\left.^{-1}\right)$ 


\begin{tabular}{|c|c|}
\hline$F F l s, s$ & $\begin{array}{l}\text { FF inputs for storing the final products at warehouse } l s \text { with technolo } \\
\left(\mathrm{MJ} / \mathrm{ton}^{-1}\right)\end{array}$ \\
\hline FFtransport total & FF inputs of transportation $\left(\mathrm{MJ} / \mathrm{ton}^{-1}\right)$ \\
\hline$\eta_{a \lg a e}$ & Rate of conversion from feedstock to microalgae \\
\hline$\eta_{\text {process }}$ & Rate of conversion from microalgae to processed microalgae \\
\hline$\eta_{\text {fuel }}$ & Rate of conversion from microalgae to biofuel \\
\hline$\eta_{\text {coproduct }}$ & Rate of conversion from microalgae to co-product \\
\hline$P f$ & Price of biofuel type $f$ \\
\hline$P_{p}$ & Price of co-product type $p$ \\
\hline$m p_{l}$ & Material price of feedstock $l$ \\
\hline$\alpha$ & Penalty cost of biofuel shortage \\
\hline rawlu,u,l & Amount of feedstock $l$ in cultivation facility $l u$ with technology $u$ \\
\hline $\mathrm{CO}_{2}$ & $\mathrm{CO} 2$ product flows \\
\hline
\end{tabular}

\begin{tabular}{ll}
\hline Decision variables & Description \\
\hline$x_{l, i, l u, v}^{t}$ & $\begin{array}{l}\text { Amount of feedstock type }{ }^{l} \text { transported from field }{ }^{i} \text { to microalgae cultivation } \\
\text { facility } l u \text { via mode }{ }^{2} \text { at time phase }\end{array}$ \\
& Amount of feedstock type ${ }^{t}$ transported from field $_{l, i, l u, u}^{t}$ to microalgae cultivation \\
& facility $l u$ with technology $u$ at time phase ${ }^{t}$ \\
$F g, l u, l h, v$ & Flow of microalgae species $g$ from microalgae cultivation facility lu to \\
& microalgae preprocessing facility $l h$ via mode $v$
\end{tabular}


Flh,la,v Flow from microalgae preprocessing facility $l h$ to biofuel bio-refinery facility $l a$ via mode $v$

$F l h, l b, v \quad$ Flow from microalgae preprocessing facility $l h$ to co-product bio-refinery facility $l b$ via mode $v$

$F f, l a, l s, v \quad$ Flow of biofuel type $f$ from biofuel bio-refinery facility $l a$ to warehouse $l s$ via mode $v$

$F p, l b, l s, v \quad$ Flow of co-product type $p$ from co-product bio-refinery facility $l b$ to warehouse $l s$ via mode $v$

$F f, l s, m, v \quad$ Flow of biofuel type $f$ from warehouse $l s$ to market $m$ via mode $v$

$F p, l s, m, v \quad$ Flow of co-product type ${ }^{p}$ from warehouse $l s$ to market $m$ via mode $v$

$q_{f, m}^{t}$

Shortage of biofuel type $f$ demanded from market $m$ at time phase ${ }^{t}$

$q_{p, m}^{t}$

Shortage of co-product type $p$ demanded from market $m$ at time phase ${ }^{t}$

$p r_{g, l u, u}^{t}$

$p r_{l h, h}^{t}$

$p r_{f, l a, a}^{t}$

Amount of microalgae species $g$ produced at microalgae cultivation facility $l u$ with technology $u$ at time phase ${ }^{t}$

Amount of microalgae processed at microalgae preprocess facility $l h$ with technology $h$ at time phase $t$

Amount of biofuel type ${ }^{f}$ produced at bio-refinery facility $l a$ with technology $a$ at time phase $t$

$p r_{p, l b, b}^{t}$

Amount of co-product type $p$ produced at co-product bio-refinery facility $l b$ with technology $b$ at time phase ${ }^{t}$

$C_{l u, u}^{t}$

Cultivation capacity of microalgae cultivation facility $l u$ with technology $u$ at time phase ${ }^{t}$

$C_{l h, h}^{t} \quad$ Preprocessing capacity of microalgae preprocess facility $l h$ with technology $h$ at time phase ${ }^{t}$ 

$C_{l a, a}^{t}$
Capacity of bio-refinery facility $l a$ with technology $a$ at time phase ${ }^{t}$
$C_{l b, b}^{t}$
Capacity of co-product bio-refinery facility $l b$ with technology $b$ at time phase
$C_{l s, s}^{t}$ $t$
Storage capacity of warehouse $l s$ with technology $s$ at time phase ${ }^{t}$

Table 6. Binary variables

\begin{tabular}{|c|c|}
\hline Binary variables & Description \\
\hline$X^{t} l u, u$ & $\begin{array}{l}1 \text {, if microalgae cultivation facility } l u \text { with technology } u \text { at time phase } t \text { is } \\
\text { constructed; otherwise, } 0 .\end{array}$ \\
\hline$X^{t} \ln , h$ & $\begin{array}{l}\text { 1, if microalgae preprocessing facility } l h \text { with technology } h \text { at time phase } t \text { is } \\
\text { constructed; otherwise, } 0 \text {. }\end{array}$ \\
\hline$X^{t} l a, a$ & $\begin{array}{l}\text { 1, if biofuel bio refinery facility } l a \text { with technology } a \text { at time phase } \mathrm{t} \text { is } \\
\text { constructed; otherwise, } 0 \text {. }\end{array}$ \\
\hline$X^{t} l b, b$ & $\begin{array}{l}\text { 1, if co-product bio refinery facility } l b \text { with technology } b \text { at time phase } t \text { is } \\
\text { constructed; otherwise, } 0 \text {. }\end{array}$ \\
\hline$X^{t} l s, s$ & 1, if warehouse $l s$ with technology ${ }^{S}$ at time phase t is constructed; otherwise, 0. \\
\hline $\mathrm{XCO}_{2}{ }^{t}$ & 1 , if carbon capture system ${ }^{i}$ is working at time phase ${ }^{t}$; otherwise, 0. \\
\hline$Z X^{t} l u, u$ & Value of difference in $X^{t} l u, u$ between ${ }^{t}$ and $t+1$ \\
\hline$Z X^{t} l h, h$ & Value of difference in $X^{t} l h, h$ between ${ }^{t}$ and $t+1$ \\
\hline$Z X^{t} l a, a$ & Value of difference in $X^{t} l a, a$ between ${ }^{t}$ and $t+1$ \\
\hline$Z X^{t} l b, b$ & Value of difference in $X^{t} l b, b$ between ${ }^{t}$ and $t+1$ \\
\hline$Z X^{t} l s, s$ & Value of difference in $X^{t} l s, s$ between ${ }^{t}$ and $t+1$ \\
\hline
\end{tabular}




\subsubsection{Objective functions}

Eq. (1) illustrates the main objective function of the study, and Equations (2) to (4) belong to the proposed framework. The main objective of the study is to maximize the profit. Therefore, the income should be maximized and the costs ought to be minimized.

$$
\begin{aligned}
& \operatorname{Max} Z=\operatorname{Revenue}-\operatorname{Cos} t \\
& \text { Revenue }=\left(\sum_{f l s m} \sum \sum F f, l s, m, v P f+\sum_{p l s m} \sum \sum F p, l s, m, v P p\right) \\
& \mathrm{CO}_{2} \\
& +\left(30000 \times\left(\frac{{ }^{2} p t}{1000}\right) X C O_{2}{ }^{t}{ }_{i}\right)
\end{aligned}
$$

Eq. (2) specifies the income, which should be maximized. The income is earned from selling the biofuels and their co-products. According to Kyoto Protocol, $30000 \mathrm{IRR}^{2}$ are paid per each reduced ton of $\mathrm{CO} 2$. This has been entailed in this equation as another source of income.

$$
\begin{aligned}
& \operatorname{Cos} t=\sum_{t}\left\{\left(\sum_{l u} \sum_{u}\left(Z X_{l u, u}^{t} f_{l u, u}^{F}+C_{l u, u}^{t} f_{l u, u}^{v}+Z X_{l u, u}^{t} L P R l u\right)\right.\right.
\end{aligned}
$$

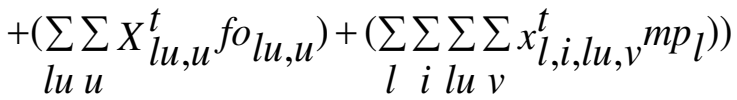

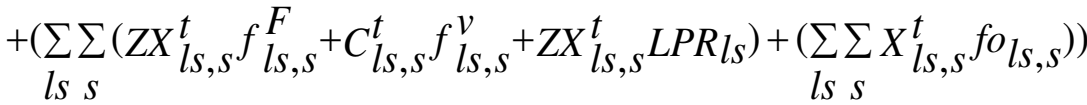

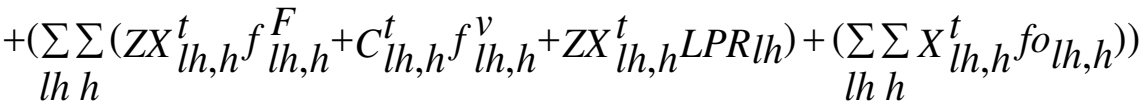

$$
\begin{aligned}
& +\left(\sum_{\text {la } a} \sum_{\text {la }, a} f_{l a, a}^{F}+C_{l a, a}^{t} f_{l a, a}^{v}+Z X_{l a, a}^{t} L_{l a} R_{l a}\right)+\left(\sum_{l a} \sum_{l a, a} X_{l a, a}^{f o}\right) \\
& \left.+\sum_{f m} \sum_{f, m} \alpha q_{l b b}^{t}\right)+\left(\sum_{l b, b}\left(Z X_{l b, b}^{t}+C_{l b, b}^{t} f_{l b, b}^{v}+Z X_{l b, b}^{t} L P R l b\right)\right. \\
& \left.+\left(\sum_{l b b} X_{l b, b}^{t} f o l b, b\right)\right\}+T C
\end{aligned}
$$

Eq. (3) shows the costs that should be minimized. The expenses include fixed costs, variable costs, land price, operational costs, feedstock price and transportation cost in different steps of the microalgae supply chain. In case there is a shortage in the biofuel production step, the shortage costs are also taken into account. In addition, TC cost has been explained in Equation (4).

${ }^{2}$ Iranian Rial currency 


$$
\begin{aligned}
& T \mathrm{C}=\text { Ctransport }_{v}\left(\sum_{l} \sum_{i \text { lu } v} \sum_{l, i, l u, v} x_{i}^{t} D I S_{i, l u}+\sum_{g} \sum_{l u l h} \sum_{l} \sum_{v} F, l u, l h, v D I S l u, l h\right. \\
& +\sum_{l h l a v} \sum_{v} F, l a, v D I S l h, l a+\sum_{l h l b v} \sum F l h, l b, v D I S l h, l b \\
& \begin{array}{l}
+\sum \sum \sum \sum F f, l a, l s, v D I S l a, l s+\sum \sum \sum \sum F p, l b, l s, v D I S l b, l s \\
\quad \text { fla } l s v
\end{array} \\
& \begin{array}{r}
\left.+\sum \sum \sum \sum F f, l s, m, v D I S_{l s, m}+\sum \sum \sum \sum F p, l s, m, v D I S l s, m\right) \\
\quad f l s m v
\end{array}
\end{aligned}
$$

253 This equation concerns the transportation cost of the feedstock, cultivated and preprocessed microalgae, 254 and biofuels and co-products.

$$
\text { EITotal }=F F \text { production }+F F \text { transportation }
$$

255

Eq. (5) refers to the second objective function of the study which seeks to minimize the environmental impacts of the supply chain. It includes Equations (6) and (7) below. This objective function is, indeed, postulated to minimize the amount of the fossil fuel input in the production and transportation steps.

$$
\begin{aligned}
& F F \text { production }=\sum_{g l u} \sum_{l u} p r_{g, l u, u}^{t} F F g, l u, u+\sum_{g} \sum_{l h} \sum_{h} p r_{g, l h, h}^{t} F F g, l h, h \\
& +\sum_{f l a} \sum_{a} p r_{f, l a, a^{t}}^{t} F F f, l a, a^{+} \sum_{p l b b} \sum_{p, l b, b} F r_{p, l b, b}^{t}
\end{aligned}
$$

Eq. (6) shows the amount of the fossil fuel input in the cultivation, preprocessing as well as biofuel and coproduct production steps.

$$
\begin{aligned}
& F F_{\text {transport }}=F \text { Ftransport } \text { total }_{l}\left(\sum_{l} \sum_{i \text { lu }} \sum_{l, i, l u, v} x^{t} D I S_{i, l u}\right.
\end{aligned}
$$

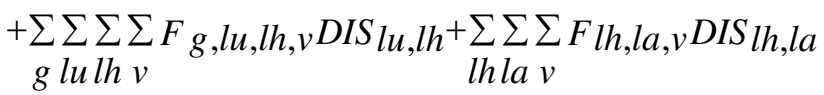

$$
\begin{aligned}
& +\sum_{l h l b v} \sum_{l h, l b, v} D I S l h, l b+\sum_{\text {fla }} \sum_{l s} \sum_{v} F f, l a, l s, v D I S l a, l s \\
& \begin{array}{l}
+\sum \sum \sum \sum F p, l b, l_{s, v} D I S l b, l_{s}+\sum \sum \sum \sum F f, l s, m, v D I S l s, m \\
\quad f \text { la ls } v
\end{array} \\
& \begin{array}{l}
\left.+\sum \sum \sum \sum F p, l s, m, v D I S l s, m\right) \\
\quad f l s m v
\end{array}
\end{aligned}
$$

Eq. (7) formulates the amount of the fossil fuel input in the transportation process at different steps of the supply chain.

\subsubsection{Constraints}



$u$ at time $t$ will at most be equal to the quantity of the feedstock that is delivered from different locations $i$ to microalgae cultivation location $l u$ and is converted into microalgae at the rate of $\eta_{a \lg a e}$.

267

$$
p r_{g, l u, u}^{t} \leq \sum_{i} x_{l, i, l u, v}^{t} \times \eta_{a \lg a e} \quad \forall g, l u, v, l
$$

$$
p r_{g, l u, u}^{t} \leq \sum_{i} x p_{l, i, l u, u}^{t} \times \eta_{a \lg a e} \quad \forall g, l u, u, l=C O_{2}
$$

270 Eq. (9) ensures that the sum of the produced microalgae species $g$ in cultivation location $l u$ with technology $271 u$ at time $t$ will at most be equal to the quantity of the $\mathrm{CO} 2$ that is delivered from different locations $i$ to 272 microalgae cultivation location $l u$ and is converted into microalgae at the rate of $\eta_{a \lg a e}$.

$$
p r_{g, l h, h}^{t} \leq \sum_{l u} F_{g, l u, l h, v} \times \eta_{\text {process }} \quad \forall g, l h, h, v
$$

273 Eq. (10) ensures that the sum of the preprocessed microalgae species $g$ in preprocessing location $l h$ with 274 technology $h$ at time $t$ will at most be equal to the quantity of the microalgae cultivated at location $l u$ and is 275 transported to processing facility $l h$ and converted into processed microalgae at the rate of $\eta_{\text {process }}$.

$$
p r_{f, l a, a}^{t} \leq \sum_{l h} F l h, l a, v \times \eta_{f u e l} \quad \forall f, l a, a, v
$$

Eq. (11) ensures that the sum of the produced biofuel type $f$ in production location la with technology $a$ at 277 time $t$ will at most be equal to the quantity of the microalgae processed at processing location $l h$ which is 278 transported to biofuel production facility $l a$ and converted into a biofuel at the rate of $\eta_{\text {fuel }}$.

$$
p r_{p, l b, b}^{t} \leq \sum_{l h} F l h, l b, v \times \eta_{\text {coproduct }} \quad \forall p, l b, b, v
$$

279 Eq. (12) ensures that the sum of the produced co-product type $p$ in production location $l b$ with technology $280 b$ at time $t$ will at most be equal to the quantity of the microalgae processed at processing location $l h$ which 281 is transported to biofuel production facility $l b$ and converted into a biofuel at the rate of $\eta_{\text {coproduct }}$. 


$$
\sum_{i} x_{l, i, l u, v}^{t} \leq \operatorname{rawlu,u,l} X_{l u, u}^{t} \quad \forall l u, u, l, v
$$

282 Eq. (13) ensures that the sum of the feedstock from all lands $i$ transported to microalgae cultivation location $283 l u$ is at most equal to the feedstock needed in cultivation location $l u$.

$$
\begin{array}{ll}
p r_{f, l a, a}^{t} \leq \sum_{m} F f, l s, m, v & \forall f, l s, l a, a, v \\
p r_{p, l b, b}^{t} \leq \sum_{m} F p, l s, m, v & \forall p, l s, l b, b, v
\end{array}
$$

284 Constraints (14) and (15) ensure that the amount of the biofuel and co-products delivered from the 285 warehouse to the customer is bigger than or equal to that of the biofuel and co-products produced in the 286 bio-refinery.

$$
\begin{array}{ll}
C_{l u, u}^{t} \leq \operatorname{Cap}_{u} X_{l u, u}^{t} & \forall l u, u, t \\
C_{l h, h}^{t} \leq \operatorname{Cap}_{h} X_{l h, h}^{t} & \forall l h, h, t \\
C_{l a, a}^{t} \leq \operatorname{Cap}_{a} X_{l a, a}^{t} & \forall l a, a, t \\
C_{l b, b}^{t} \leq \operatorname{Cap}_{b} X_{l b, b}^{t} & \forall l b, b, t \\
C_{l s, s}^{t} \leq \operatorname{Cap}_{s} X_{l s, s}^{t} & \forall l s, s, t
\end{array}
$$

287 Constraints (16) to (20) ensure that the amount of production in different steps of the MBCSCN will not 288 surpass the maximum allowable capacity of the respective steps.

$$
\begin{array}{ll}
C_{l u, u}^{t-1} \leq C_{l u, u}^{t} & \forall l u, u, t=2, \ldots, T \\
C_{l s, s}^{t-1} \leq C_{l s, s}^{t} & \forall l s, s, t=2, \ldots, T \\
C_{l h, h}^{t-1} \leq C_{l h, h}^{t} & \forall l h, h, t=2, \ldots, T \\
C_{l a, a}^{t-1} \leq C_{l a, a}^{t} & \forall l a, a, t=2, \ldots, T \\
C_{l b, b}^{t-1} \leq C_{l b, b}^{t} & \forall l b, b, t=2, \ldots, T
\end{array}
$$


289 Constraints (21) to (25) ensure that the capacity of each step of the MBCSCN is not less than its capacity 290 in the previous period.

$$
\begin{array}{ll}
X_{l u, u}^{t-1} \leq X_{l u, u}^{t} & \forall l u, u, t=2, \ldots, T \\
X_{l h, h}^{t-1} \leq X_{l h, h}^{t} & \forall l h, h, t=2, \ldots, T \\
X_{l a, a}^{t-1} \leq X_{l a, a}^{t} & \forall l a, a, t=2, \ldots, T \\
X_{l b, b}^{t-1} \leq X_{l b, b}^{t} & \forall l b, b, t=2, \ldots, T \\
X_{l s, s}^{t-1} \leq X_{l s, s}^{t} & \forall l s, s, t=2, \ldots, T
\end{array}
$$

291 Constraints (26) to (30) ensure that the facility of each step of the MBCSCN will not be closed after it is 292 opened.

$$
\begin{array}{ll}
Z X_{l u, u}^{t}=X_{l u, u}^{t}-X_{l u, u}^{t-1} & \forall l u, u, t=2, \ldots, T \\
Z X_{l h, h}^{t}=X_{l h, h}^{t}-X_{l h, h}^{t-1} & \forall l h, h, t=2, \ldots, T \\
Z X_{l a, a}^{t}=X_{l a, a}^{t}-X_{l a, a}^{t-1} & \forall l a, a, t=2, \ldots, T \\
Z X_{l b, b}^{t}=X_{l b, b}^{t}-X_{l b, b, c}^{t-1} & \forall l b, b, t=2, \ldots, T \\
Z X_{l s, s}^{t}=X_{l s, s}^{t}-X_{l s, s}^{t-1} & \forall l s, s, t=2, \ldots, T
\end{array}
$$

293 Constraints (31) to (35) ensure that there will not be two facilities for each step of the MBCSCN in one 294 location.

$$
\begin{array}{ll}
Z X_{l u, u}^{t}=X_{l u, u}^{t} & \forall l u, u, t=1 \\
Z X_{l h, h}^{t}=X_{l h, h}^{t} & \forall l h, h, t=1 \\
Z X_{l a, a}^{t}=X_{l a, a}^{t} & \forall l a, a, t=1 \\
Z X_{l b, b}^{t}=X_{l b, b}^{t} & \forall l b, b, t=1 \\
Z X_{l s, s}^{t}=X_{l s, s}^{t} & \forall l s, s, t=1
\end{array}
$$


295 Constraints (36) to (40) show the number of the facilities for each step of the MBCSCN that are established 296 in the first year.

$$
\begin{array}{ll}
R L_{\text {cultivation }} X_{l u, u}^{t} \leq A L S_{l u} & \forall l u, u, t \\
R_{\text {preprocess }} X_{l h, h}^{t} \leq A L S_{l h} & \forall l h, h, t \\
R L_{\text {fuel }} X_{l a, a}^{t} \leq A L S_{l a} & \forall l a, a, t \\
R L_{\text {coproduct }} X_{l b, b}^{t} \leq A L S l b & \forall l b, b, t \\
R L_{\text {storage }} X_{l s, s}^{t} \leq A L S l s & \forall l s, s, t
\end{array}
$$

297 Constraints (41) to (45) ensure that the land area needed for each step of the MBCSCN should not exceed 298 the available land area for that step.

$$
\begin{array}{ll}
p r_{g, l u, u}^{t} \leq C_{l u, u}^{t} & \forall l u, u, g, t \\
p r_{l h, h}^{t} \leq C_{l h, h}^{t} & \forall l h, h, t \\
p r_{f, l a, a}^{t} \leq C_{l a, a}^{t} & \forall l a, a, f, t \\
p r_{p, l b, b}^{t} \leq C_{l b, b}^{t} & \forall l b, b, p, t
\end{array}
$$

299 Constraints (46) to (49) ensure that the amount of production in each step of the MBCSCN will not exceed 300 the capacity designed for that location.

$$
\sum_{f l s} F f, l s, m, v+\sum_{f} q_{f, m}^{t}=\sum_{f} D_{m, f}^{t} \quad \forall m, v, t
$$

Constraints (50) shows the customer demand for biofuel type $f$ from warehouse $l s$ to customer $m$

$$
\sum_{p l s} \sum_{p, l s, m, v^{+}} \sum_{p} q_{p, m}^{t}=\sum_{p} D_{m, p}^{t} \quad \forall m, v, t
$$

Constraint (51) regards the customer demand for co-product type $p$ from warehouse $l s$ to customer $m$.

$$
\sum_{l u} X_{l u, u}^{t} \leq 1
$$




$$
\begin{array}{ll}
\sum_{l h} X_{l h, h}^{t} \leq 1 & \forall h, t \\
\sum_{l a} X_{l a, a}^{t} \leq 1 & \forall a, t \\
\sum_{l b} X_{l b, b}^{t} \leq 1 & \forall b, t \\
\sum_{l s} X_{l s, s}^{t} \leq 1 & \forall s, t
\end{array}
$$

301 Constraints (52) to (56) ensure that, for each step of the MBCSCN with any type of technology, only one 302 facility will be established.

$$
\begin{aligned}
& x_{l, i, l u, v}^{t} \geq 0 \\
& \forall l, i, l u, v, t \\
& x_{l, i, l u, u}^{t} \geq 0 \quad \forall l, i, l u, u, t \\
& F_{g, l u, l h, v} \geq 0 \quad \forall g, l u, l h, v \\
& F l h, l a, v \geq 0 \quad \forall l h, l a, v \\
& F l h, l b, v \geq 0 \quad \forall l h, l b, v \\
& F_{f, l a, l s, v} \geq 0 \quad \forall f, l a, l s, v \\
& F_{p, l b, l s, v} \geq 0 \quad \forall p, l b, l s, v \\
& F_{f, l s, m, \nu} \geq 0 \quad \forall f, l s, m, v \\
& F_{p, l s, m, v} \geq 0 \quad \forall p, l s, m, v \\
& q_{f, m}^{t} \geq 0 \quad \forall f, m, t \\
& p r_{g, l u, u}^{t} \geq 0 \quad \forall g, l u, u, t \\
& p r_{l h, h^{t}}^{\geq 0} \quad \forall l h, h, t
\end{aligned}
$$




$$
\begin{aligned}
& p r_{f, l a, a}^{t} \geq 0 \quad \forall f, l a, a, t \\
& p r_{p, l b, b}^{t} \geq 0 \quad \forall p, l b, b, t \\
& C_{l u, u}^{t} \geq 0 \quad \forall l u, u, t \\
& C_{l s, s}^{t} \geq 0 \quad \forall l s, s, t \\
& C_{l h, h}^{t} \geq 0 \quad \forall l h, h, t \\
& C_{l a, a}^{t} \geq 0 \quad \forall l a, a, t \\
& C_{l b, b}^{t} \geq 0 \quad \forall l b, b, t \\
& X^{t} l u, u=\{0,1\} \quad \forall l u, u, t \\
& X^{t} l s, s=\{0,1\} \quad \forall l s, s, t \\
& X^{t} l h, h=\{0,1\} \quad \forall l h, h, t \\
& X^{t} l a, a=\{0,1\} \quad \forall l a, a, t \\
& X^{t} l b, b=\{0,1\} \quad \forall l b, b, t \\
& \mathrm{XCO}_{2}{ }^{t}{ }_{i}=\{0,1\} \quad \forall i, t \\
& Z X^{t} l u, u=\{0,1\} \quad \forall l u, u, t \\
& Z X_{l s, s}^{t}=\{0,1\} \quad \forall l s, s, t \\
& Z X^{t} l h, h=\{0,1\} \quad \forall l h, h, t
\end{aligned}
$$




$$
\begin{aligned}
& Z^{t} l a, a=\{0,1\} \quad \forall l a, a, t \\
& Z X^{t} l b, b=\{0,1\} \quad \forall l b, b, t
\end{aligned}
$$

\subsection{Solution method}

305 In the $\varepsilon$-constraint method, one of the objective functions is chosen and the other ones are used as 306 constraints. Efficient solutions to the problem are obtained through the parametrical variation in the RHS of the constrained objective functions. Assume the following multi-objective optimization problem:

$$
\begin{aligned}
& \max _{\text {st }}\left(\mathrm{f}_{1}(\mathrm{x})+\mathrm{f}_{2}(\mathrm{x}), \mathrm{L}_{p}, \mathrm{f}_{p}(\mathrm{x})\right) \\
& \\
& \\
& \quad \mathrm{x} \in \mathrm{s},
\end{aligned}
$$

308 The general form of the $\varepsilon$-constraint model is as shown below (Mavrotas, 2009):

$$
\begin{array}{ll}
\max & \mathrm{f}_{1}(\mathrm{x}) \\
\text { st } & \mathrm{f}_{2}(\mathrm{x}) \geq e_{2}, \\
& \mathrm{f}_{3}(\mathrm{x}) \geq e_{3}, \\
& \mathrm{~L} \\
\mathrm{f}_{p}(\mathrm{x}) \geq e_{p}, \\
\mathrm{x} \in \mathrm{s}
\end{array}
$$

\section{Case study and the results}

The proposed model was implemented through a case study to specify its feasibility in Iran. The case study was conducted in this country due to a) the increasing demand for energy, b) the high level of demand for medication, health products and foodstuffs, c) the increased amount of environmental pollutants in large cities and the motivating policies to decrease them, d) the great diversity of microalgae species on the southern coasts of Iran, e) enough sunlight, and f) the existence of barren and inexpensive farm lands for microalgae cultivation (Arabi et al., 2019b; Mohseni et al., 2016).

\subsection{The criteria to select locations for algae cultivation}


criteria were then categorized into 12 sub-criteria. Table 7 presents the corresponding data obtained from an active corporation ${ }^{3}$ in this field in Iran and some other studies (Mohseni et al., 2016; Najafi et al., 2011). The criteria are evaluated as follows:

- Land price: The money spent on buying or renting a piece of land can positively or negatively affect the final cost of the supply chain and lead to more or less profit.

- Job opportunities: The development of this industry in an area can create jobs for the neighboring residents.

- Distance to the customer: In order to sell the end products, shorter distance to the customer will reduce the transportation cost.

- Land use: The land used for microalgae cultivation should not be a part of grassland, jungle or farmland; it should be located in a sizable area. Therefore, finding cheaper land can be helpful in this regard (Adenle, Haslam, \& Lee, 2013; Coleman et al., 2014; Mohseni et al., 2016).

- Distance to water resources: This criterion refers to saline water, fresh water and wastewater. In order to deliver a huge amount of water to microalgae pools or PBR, there is a need for pipelines and a pumping system, but this imposes extra costs. Therefore, locations with easy access to water resources or previously built WWTs should be looked for so as to decrease the water costs (Coleman et al., 2014; Mohseni et al., 2016; Zhou et al., 2014).

- Distance to a power plant: The delivery of $\mathrm{CO} 2$ to microalgae cultivation pools requires pipes and pumps, which entails the same costs as water delivery does. Therefore, it is necessary to build cultivation locations with the least distance to CO2 production sites (Kim et al., 2013; Mohseni et al., 2016; Pokoo-Aikins et al., 2010; Sharma et al., 2015).

- Distance to nutrient resource markets: In order to buy a feedstock and nutrients for micro-algae cultivation, a short distance to the resource market will be cost-effective.

- Humidity: Sufficient humidity in the location will lead to suitable conditions for microalgae cultivation (Adenle et al., 2013; Chisti, 2013).

- Solar radiation: The more sunlight during the year, the faster the microalgae will grow (Adenle et al., 2013; Chisti, 2013).

- Temperature: Most of the commonly cultured species of microalgae can tolerate temperatures from $16^{\circ} \mathrm{C}$ to $27^{\circ} \mathrm{C}$. Temperatures lower than $16^{\circ} \mathrm{C}$ slow the growth down, whereas those higher than $35^{\circ} \mathrm{C}$ are lethal for a number of species.

\footnotetext{
${ }^{3}$ Qeshm Microalgae Biorefinery (QMAB)
} 
351 Table 7. The weights of the criteria and the sub-criteria to select the candidate cities for microalgae 352 cultivation

\begin{tabular}{|c|c|c|c|}
\hline Criteria & Weight & Sub-criteria & Weight \\
\hline \multirow[t]{4}{*}{ Land } & 0.1845 & Land price (IRR) & 0.2890 \\
\hline & & Job opportunities & 0.1800 \\
\hline & & Distance to the market $(\mathrm{Km})$ & 0.3000 \\
\hline & & Land use & 0.2310 \\
\hline \multirow{5}{*}{$\begin{array}{l}\text { Accessibility } \\
\text { of resources }\end{array}$} & 0.4733 & Distance to saline water (sea) $(\mathrm{Km})$ & 0.1480 \\
\hline & & Distance to fresh water $(\mathrm{Km})$ & 0.1701 \\
\hline & & Distance to WWT $(\mathrm{Km})$ & 0.2132 \\
\hline & & Distance to power plant $(\mathrm{Km})$ & 0.3207 \\
\hline & & Distance to nutrient resource market $(\mathrm{Km})$ & 0.1480 \\
\hline \multirow[t]{3}{*}{ Climate } & 0.3422 & Humidity (RH) & 0.1376 \\
\hline & & Solar radiation $(\mathrm{Kwh} / \mathrm{m} 2)$ & 0.4836 \\
\hline & & Temperature $\left({ }^{\circ} \mathrm{C}\right)$ & 0.3788 \\
\hline
\end{tabular}

\subsection{Results of the first stage: Identifying the locations for microalgae cultivation}

356 In order to identify the locations for cultivation, it is necessary to choose areas with higher priority to 357 establish the microalgae cultivation facilities. In this case study, as Table 8 suggests, some Iranian cities 358 were found to have the required capabilities for this purpose (Mohseni et al., 2016; Najafi et al., 2011; 359 Tzeng \& Huang, 2011).

360 Table 8. Candidate cities

\begin{tabular}{llllllllll}
\hline No. & City & No. & City & No. & City & No. & City & No. & City \\
\hline 1 & Ahvaz & 8 & Birjand & 15 & Isfahan & 22 & Qeshm & 29 & Shiraz \\
2 & Arak & 9 & Bojnurd & 16 & Jask & 23 & Qom & 30 & Tabriz
\end{tabular}




$\begin{array}{llllllllll}3 & \text { Ardabil } & 10 & \text { Bushehr } & 17 & \text { Kerman } & 24 & \text { Rasht } & 31 & \text { Tehran } \\ 4 & \text { Bandar Abbas } & 11 & \text { Chabahar } & 18 & \text { Kermanshah } & 25 & \text { Sanandij } & 32 & \text { Urmia } \\ 5 & \text { Bandar Kangan } & 12 & \text { Chalus } & 19 & \text { Khorram abad } & 26 & \text { Sari } & 33 & \text { Yasuj } \\ 6 & \text { Bandar-e Lengeh } & 13 & \text { Gorgan } & 20 & \text { Mashhad } & 27 & \text { Semnan } & 34 & \text { Yazd } \\ 7 & \text { Bandar-e Mahshahr } & 14 & \text { Hamedan } & 21 & \text { Qazvin } & 28 & \text { Shahrekord } & 35 & \text { Zanjan }\end{array}$

\subsection{Solving the multi-objective optimization model using the $\varepsilon$-constraint method}

The proposed multi-objective function model was solved with the $\varepsilon$-constraint method, the CPLEX solver and the GAMs software on a computer equipped with the Intel ${ }^{\circledR}$ Core(TM) i7-7700 HQ operating at 2.81 $\mathrm{GHz}$.

The model was first solved with the economic objective function as the main objective function. The lower and upper bounds of the main objective function were 0 and 834484198 in epsilon values respectively. The problem was, indeed, solved according to the main objective function and the determined epsilon values. Table 9 shows the results of solving the model with 10 epsilon values. The first objective function is regarded economic considerations and aimed to maximize the profit. The second objective function was about environmental impacts and sought to minimize the fossil fuel consumption. Basically, economic and environmental features are widely known as sustainability determiners. Although economic considerations make up the top-priority objective function, the importance of environmental sustainability cannot be ignored (Rabbani, Momen, Akbarian-Saravi, Farrokhi-Asl, \& Ghelichi, 2020). The former is concerned with the maximization of the economic profit. Since it attracts private-sector investors and expands the industry, it is considered more important than environmental issues. Therefore, it was set as the main objective function in this study.

According to the Pareto optimal solutions for the economic and fossil energy input problems (Figure 2), decision makers can choose a preferred point. For example, at the point with $\varepsilon$ of $5.38 \mathrm{E}+08$, the profit value is 538,627,026 million Rials, while the fossil energy input is 8.9 MJ. When more algal products are produced, more fossil energy is needed to produce the end products and transport them to the customer. Contrary to the first objective function, which induces more fossil fuel consumption, the second objective function aims at minimizing the consumption of those fuels throughout the MBCSCN. Indeed, the less fossil fuel is consumed, the less GHG is emitted. Therefore, in the Pareto optimal solutions, the model seeks a breakeven point where the value of each objective function is satisfied while its total value is optimized.

Table 9. Multi-objective model results

\begin{tabular}{llll}
\hline Points & E & Economic benefit $\left(\mathrm{MIRR}^{4}\right)$ & Fossil energy input (MJ)
\end{tabular}

\footnotetext{
${ }^{4}$ Million Iranian Rials
} 


\begin{tabular}{llll}
\hline 1 & 0 & 0 & 0 \\
2 & $9.92 \mathrm{E}+07$ & $9.92 \mathrm{E}+07$ & 16.71 \\
3 & $1.93 \mathrm{E}+08$ & $1.93 \mathrm{E}+08$ & 15.18 \\
4 & $2.87 \mathrm{E}+08$ & 13.65 \\
5 & $3.82 \mathrm{E}+08$ & $3.82 \mathrm{E}+08$ & 12.12 \\
6 & $4.76 \mathrm{E}+08$ & 10.59 \\
7 & $5.76 \mathrm{E}+08$ & $5.38 \mathrm{E}+08$ & 8.9 \\
8 & $5.38 \mathrm{E}+08$ & $6.73 \mathrm{E}+08$ & 7.5 \\
9 & $6.73 \mathrm{E}+08$ & $7.93 \mathrm{E}+08$ & 6.2 \\
10 & $7.93 \mathrm{E}+08$ & $8.34 \mathrm{E}+08$ & 4.8 \\
\hline
\end{tabular}

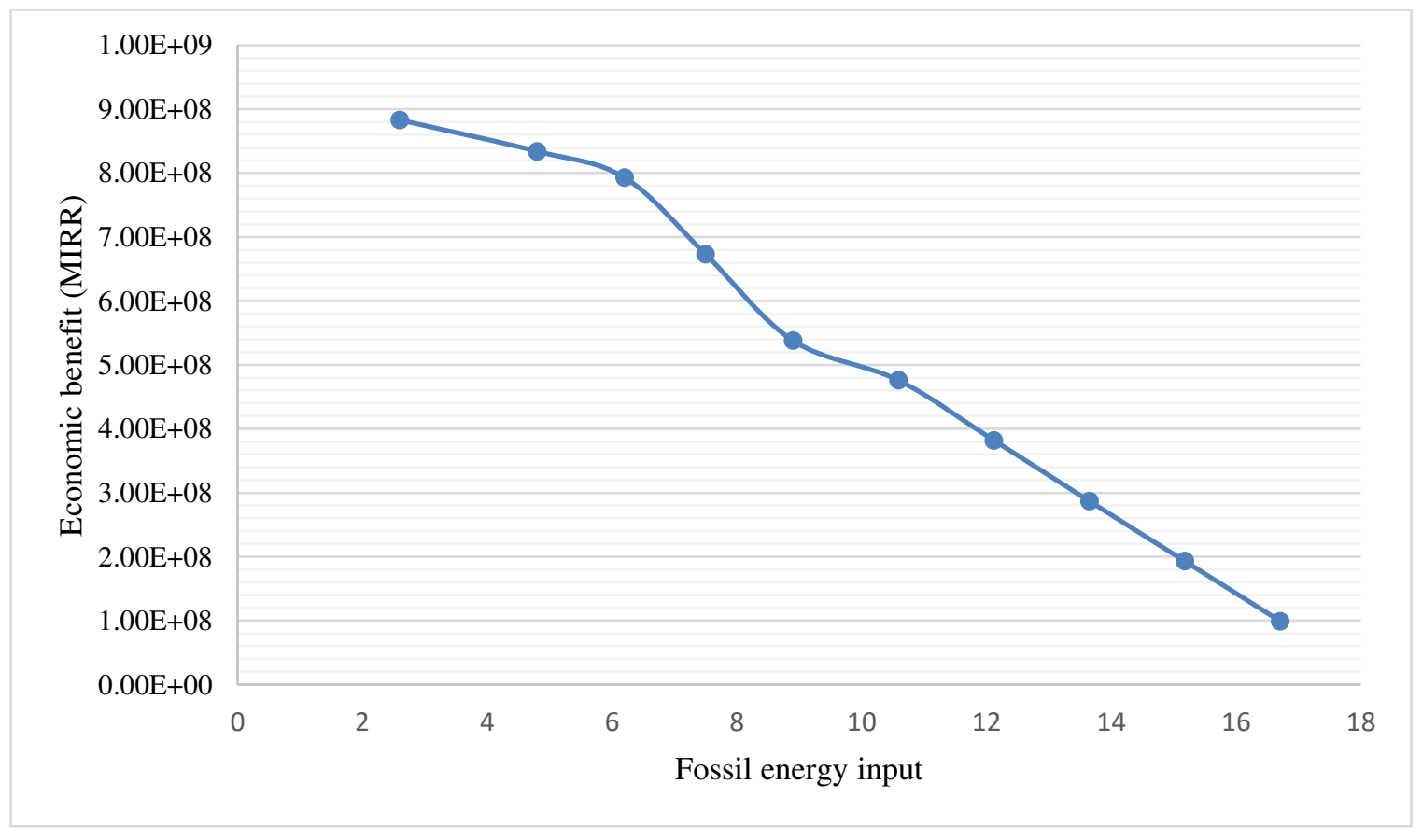

Fig. 2. Pareto optimal solutions

\section{$392 \quad 3.4$. Results of the second stage}

393 The optimal costs include the fixed, variable and operational costs for each step of the MBCSCN. The 394 transportation costs relate to the transporting of the feedstock from the feedstock market to the microalgae 


\begin{tabular}{llll}
\hline No. & City & Cultivation technology & \\
\cline { 4 - 4 } & & Open pond & Photo bioreactor \\
\hline 4 & Bandar Abbas & C,S,D & \\
5 & Bandar Kangan & S & \\
6 & Bandar-e Lengeh & D & \\
7 & Bandar-e Mahshahr & S,D & D \\
10 & Bushehr & C,S,D & D \\
11 & Chabahar & C,S,D & \\
16 & Jask & C,S & D \\
22 & Qeshm & C,S & \\
26 & Sari & D & \\
32 & Urmia & C &
\end{tabular}

cultivation sites, then to the preprocessing facilities, then to the biofuel and co-products bio-refinery, then to the end-products warehouse, and finally to the customers in Iran. The amount of fossil fuel affecting the environment is studied in all the steps of the supply chain. It is noteworthy that all of these studies have been done for a 5-year planning horizon.

Table 8 shows 35 candidate cities where investments can be made for microalgae cultivation. With regard to the results obtained from the AHP method, 10 cities are selected for constructing microalgae cultivation facilities (Table 10). In addition, Fig. 3 illustrates the technologies and the types of microalgae to be used in the selected cities. According to the results of this model, most of the cultivation locations use Open Pond technology for microalgae cultivation owing to its lower cost.

Table 10. Cities selected for constructing cultivation facilities with the corresponding technologies and microalgae species

Abbreviations: C: Chlorella vulgaris , S: Spirulina platensis , D: Dunaliella salina

407 The optimal microalgae preprocessing locations are placed in the cultivation sites, which leads to the 408 reduction of transportation costs (Fig. 4) (Ismail et al., 2020). 


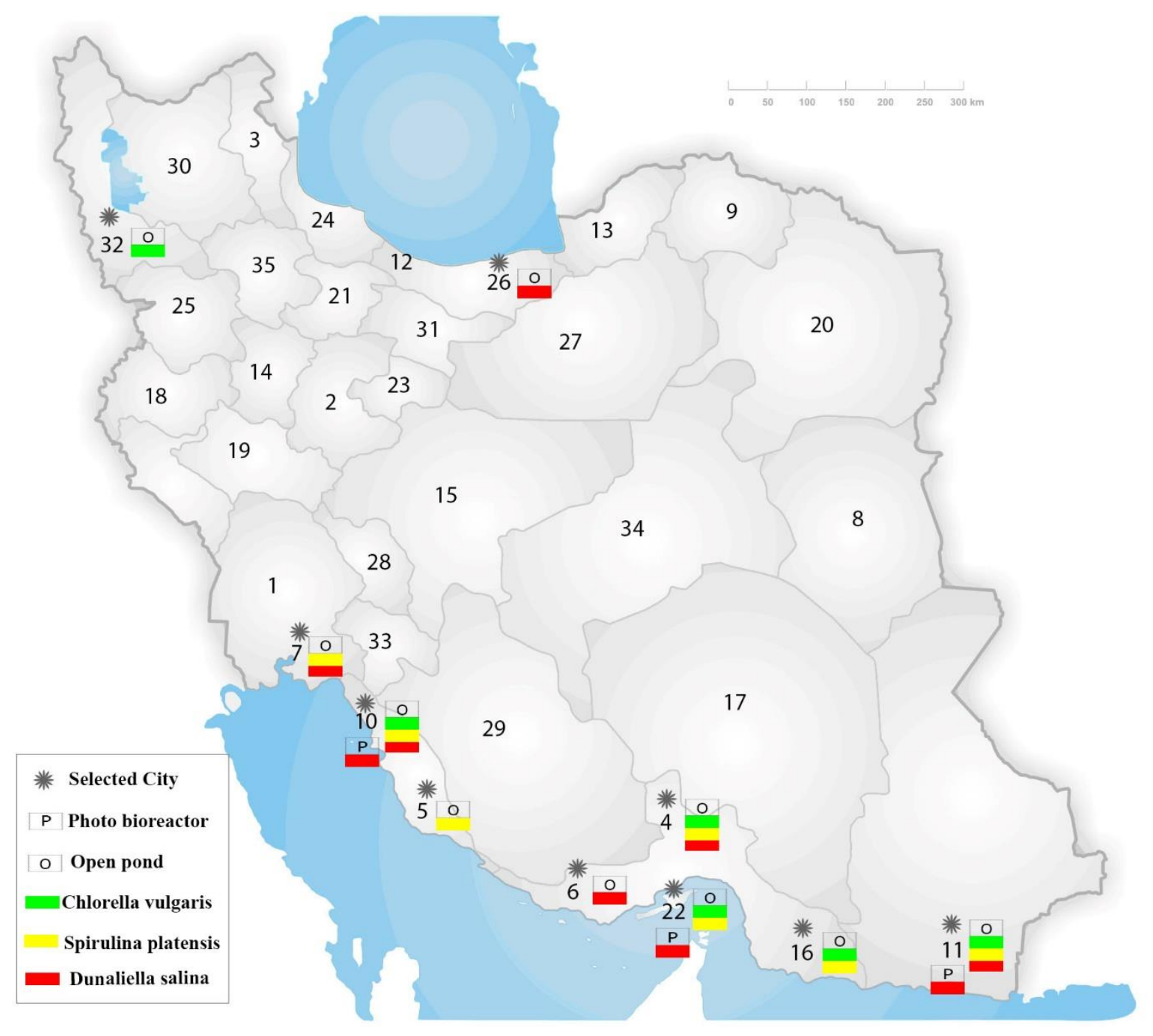

410 Fig. 3. Cities selected for constructing cultivation facilities with the corresponding technologies and 411 microalgae species

412 Table 11 shows the technologies applied in the preprocess step. In this study, the preprocess step involves 413 two operations, harvesting and dewatering ae well as drying. Each of these operations needs a different 414 technology with regard to the species of the microalgae (Gutiérrez-Arriaga et al., 2014; Ismail et al., 2020). 415 In the preprocess step, three technologies are applied (Arabi et al., 2019a). 


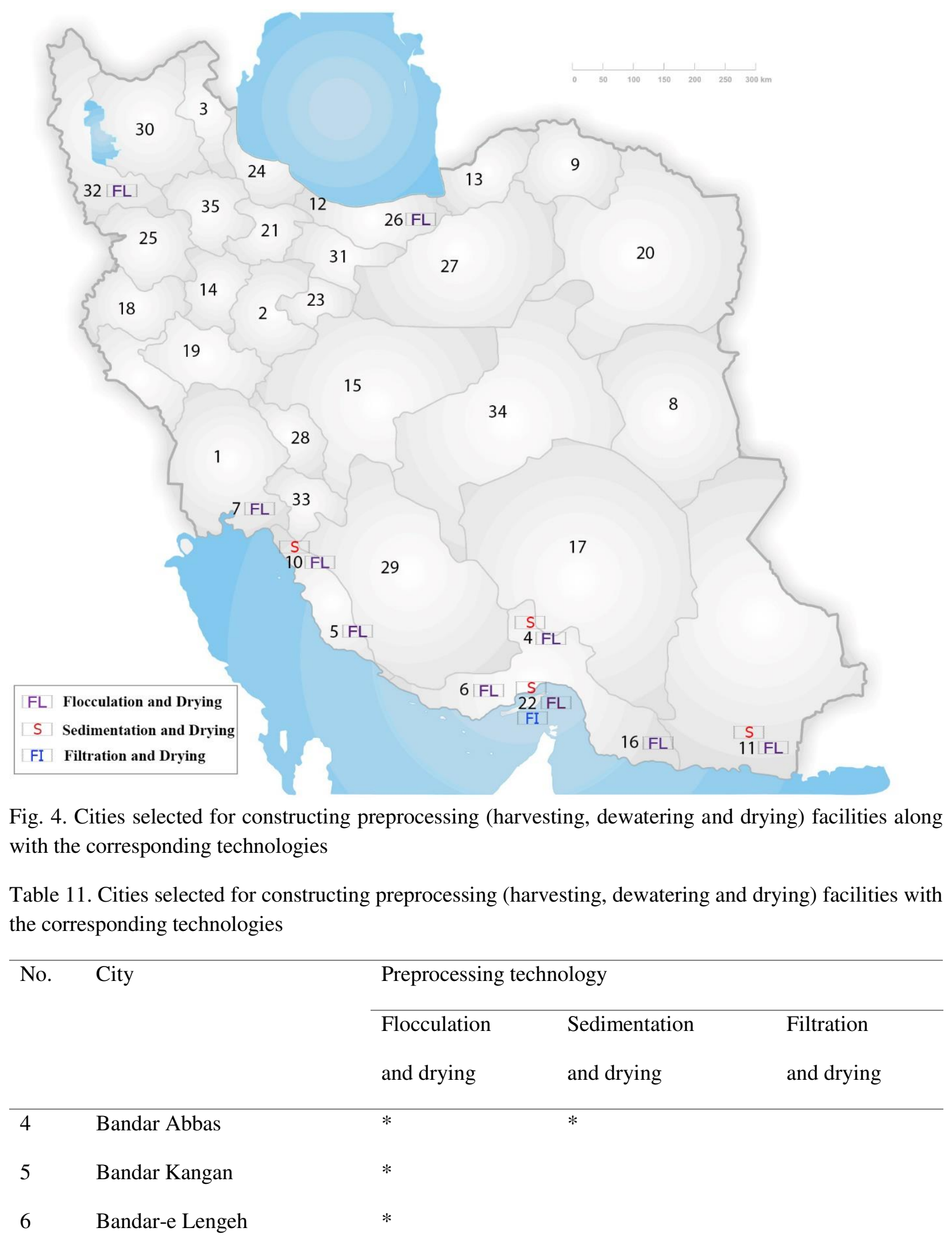




\begin{tabular}{|c|c|c|c|c|}
\hline 7 & Bandar-e Mahshahr & $*$ & & \\
\hline 10 & Bushehr & $*$ & $*$ & \\
\hline 11 & Chabahar & $*$ & $*$ & \\
\hline 16 & Jask & $*$ & & \\
\hline 22 & Qeshm & $*$ & $*$ & $*$ \\
\hline 26 & Sari & $*$ & & \\
\hline 32 & Urmia & $*$ & & \\
\hline
\end{tabular}

421

422 Fig. 5 illustrates 13 cities for biofuel production, and Fig. 6 introduces nine cities to produce co-products.

423 Three technologies have been applied in the biofuel production, and the two technologies of anaerobic

424 digestion and thermal treatment have served to produce co-products. Moreover, biodiesel, bioethanol and

425 biogas (methane) are the products obtained from the selected bio-refineries, and astaxanthin, health

426 products, aquaculture, $\beta$-carotene and human and animal foodstuffs are the end products taken from the

427 selected co-product production facilities (Tables 12 and 13). 


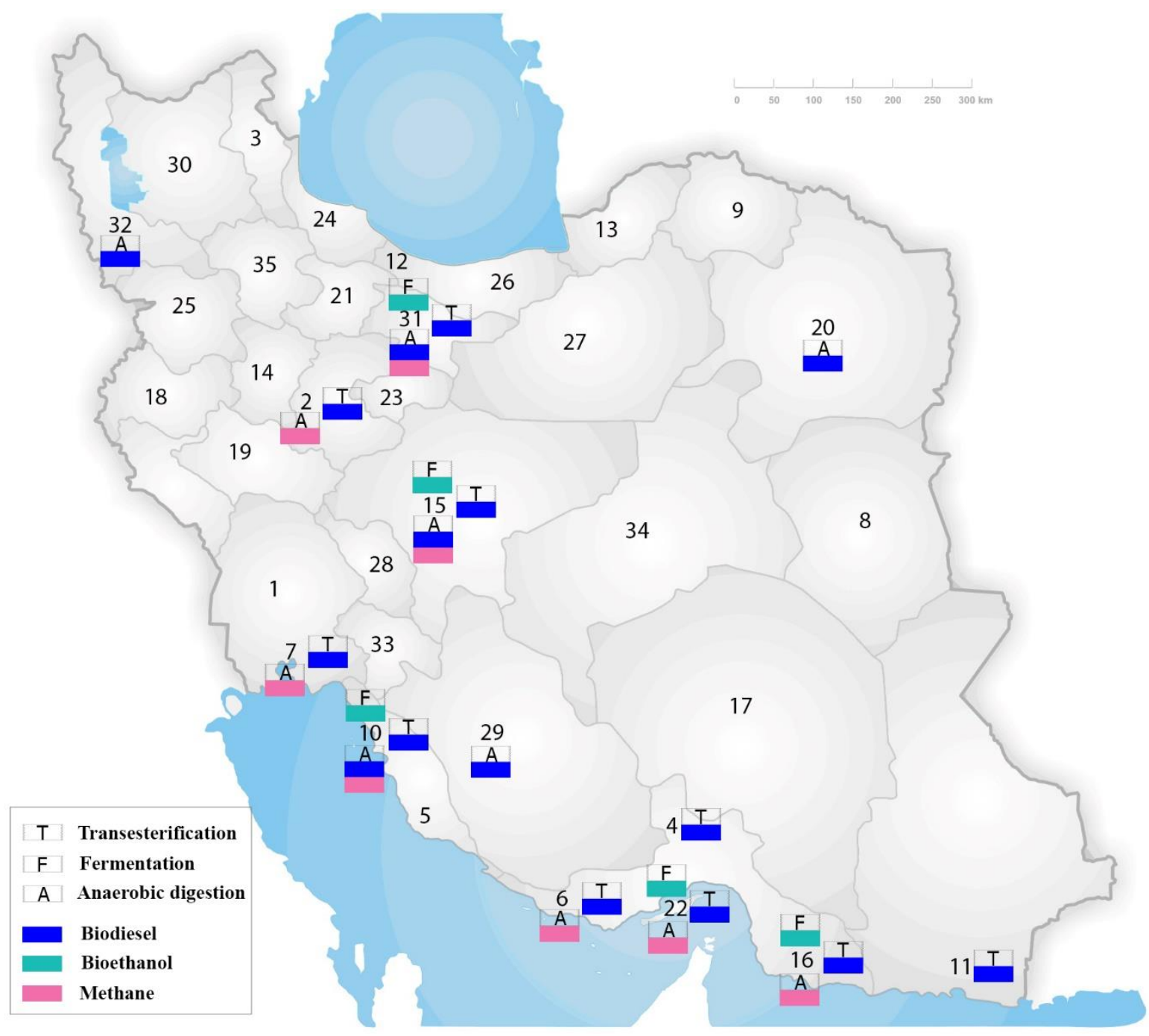

429 Fig. 5. Cities selected for constructing bio-refinery facilities to produce biofuels with the corresponding 430 technologies

431

432 Table 12. Cities selected for constructing bio-refinery facilities to produce biofuels with the corresponding 433 technologies

\begin{tabular}{lllll}
\hline \multirow{2}{*}{ No. } & City & \multicolumn{2}{c}{ Bio-refinery technology to produce biofuels } & \\
\cline { 3 - 4 } & & Transesterification & Fermentation & Anaerobic digestion \\
\hline 2 & Arak & BD & M \\
4 & Bandar Abbas & & \\
6 & Bandar-e Lengeh & BD & M
\end{tabular}




$\begin{array}{lllll}7 & \text { Bandar-e Mahshahr } & \text { BD } & & \text { M } \\ 10 & \text { Bushehr } & \text { BD } & \text { BE } & \text { BD,M } \\ 11 & \text { Chabahar } & \text { BD } & & \\ 15 & \text { Isfahan } & \text { BD } & \text { BE } & \text { BD,M } \\ 16 & \text { Jask } & \text { BD } & \text { BE } & \text { M } \\ 20 & \text { Mashhad } & & & \text { BD } \\ 22 & \text { Qeshm } & \text { BD } & \text { BE } & \text { M } \\ 29 & \text { Shiraz } & & & \text { BD } \\ 31 & \text { Tehran } & \text { BD } & \text { BE } & \text { BD,M } \\ 32 & \text { Urmia } & & & \text { BD }\end{array}$

Abbreviations: BD: Biodiesel, BE: Bioethanol, M: Biogas (Methane)

435 Table 13. Cities selected for constructing bio-refinery facilities to produce co-products with the 436 corresponding technologies

\begin{tabular}{|c|c|c|c|}
\hline \multirow[t]{2}{*}{ No. } & \multirow[t]{2}{*}{ City } & \multicolumn{2}{|c|}{ Bio-refinery technology to produce co-products } \\
\hline & & Thermal treatment & Anaerobic digestion \\
\hline 2 & Arak & & $\mathrm{H}, \mathrm{B}, \mathrm{F}$ \\
\hline 4 & Bandar Abbas & $\mathrm{A}, \mathrm{H}, \mathrm{F}$ & \\
\hline 10 & Bushehr & $\mathrm{A}, \mathrm{H}, \mathrm{F}$ & $\mathrm{C}, \mathrm{B}$ \\
\hline 11 & Chabahar & $\mathrm{A}, \mathrm{H}, \mathrm{F}$ & \\
\hline 15 & Isfahan & & $\mathrm{H}, \mathrm{B}, \mathrm{F}$ \\
\hline 16 & Jask & & $\mathrm{A}, \mathrm{H}, \mathrm{C}, \mathrm{B}$ \\
\hline 22 & Qeshm & & $\mathrm{H}, \mathrm{C}, \mathrm{B}$ \\
\hline 29 & Shiraz & & $\mathrm{H}, \mathrm{B}$ \\
\hline 31 & Tehran & $\mathrm{A}, \mathrm{H}, \mathrm{F}$ & $\mathrm{C}, \mathrm{B}$ \\
\hline
\end{tabular}


This research has brought warehouse facilities into account to store the end products. Table 14 refers to 13 cities for biofuel products and eight others for co-products; they have been selected to store the end products (Fig. 7). The end products are sent from their warehouses to the customer. Fig. 8 shows the biofuel and coproducts customers. They are chosen based on their demand for the end products in each city.

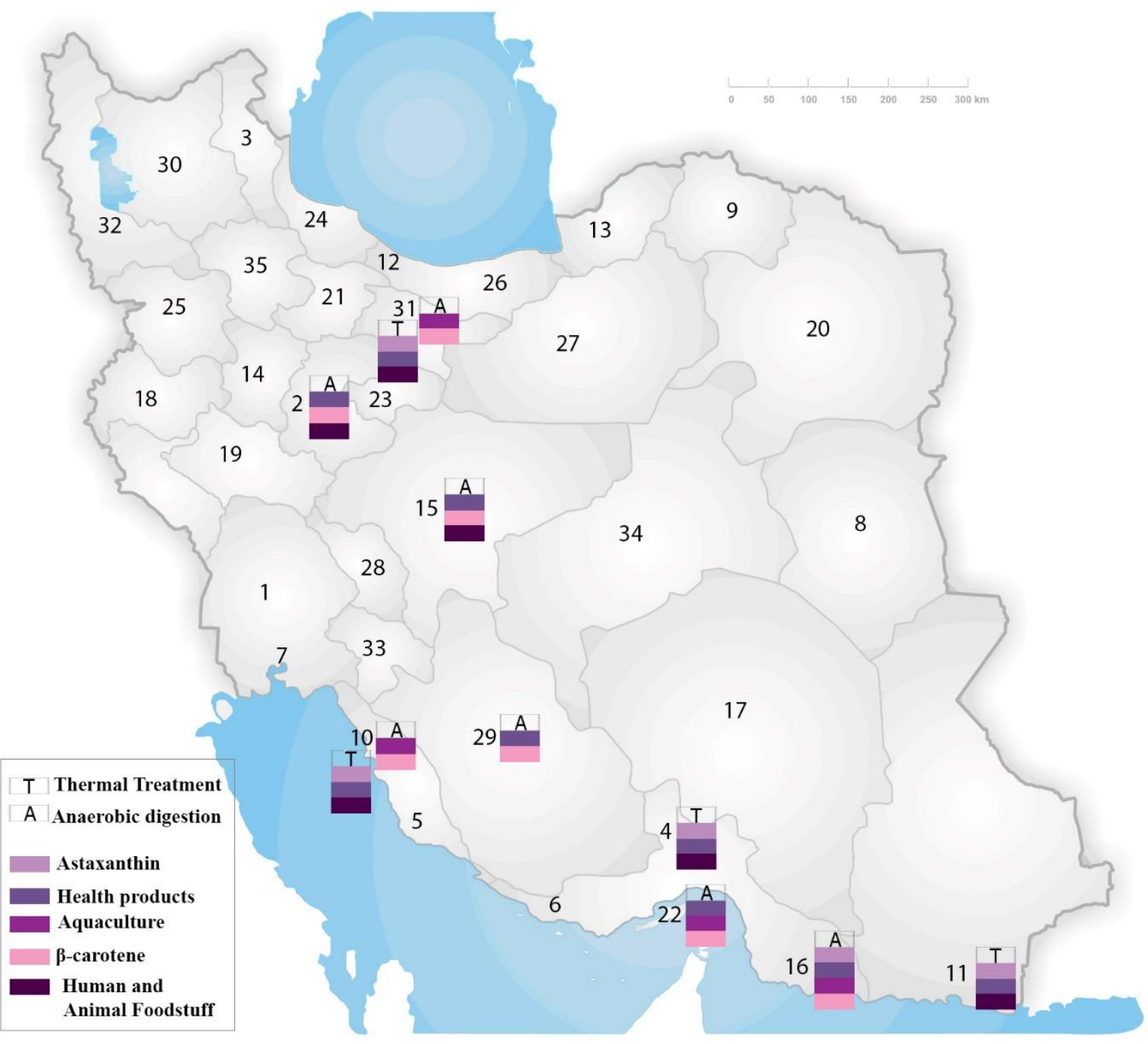

442 Fig. 6. Cities selected for constructing bio-refinery facilities to produce co-products with the 443 corresponding technologies

445 Table 14. Cities selected for constructing warehouses

\begin{tabular}{llll} 
No. & City & \multicolumn{2}{c}{ Warehouse } \\
\cline { 3 - 4 } & & Biofuels & Co-products \\
\hline 2 & Arak & $*$ & $*$
\end{tabular}




$\begin{array}{llll}4 & \text { Bandar Abbas } & * & * \\ 6 & \text { Bandar-e Lengeh } & * & * \\ 7 & \text { Bandar-e Mahshahr } & * & * \\ 10 & \text { Bushehr } & * & * \\ 11 & \text { Chabahar } & * & * \\ 15 & \text { Isfahan } & * & * \\ 16 & \text { Jask } & * \\ 20 & \text { Mashhad } & * & * \\ 22 & \text { Qeshm } & \text { Shiraz } & * \\ 31 & \text { Tehran } & \text { Urmia } & *\end{array}$




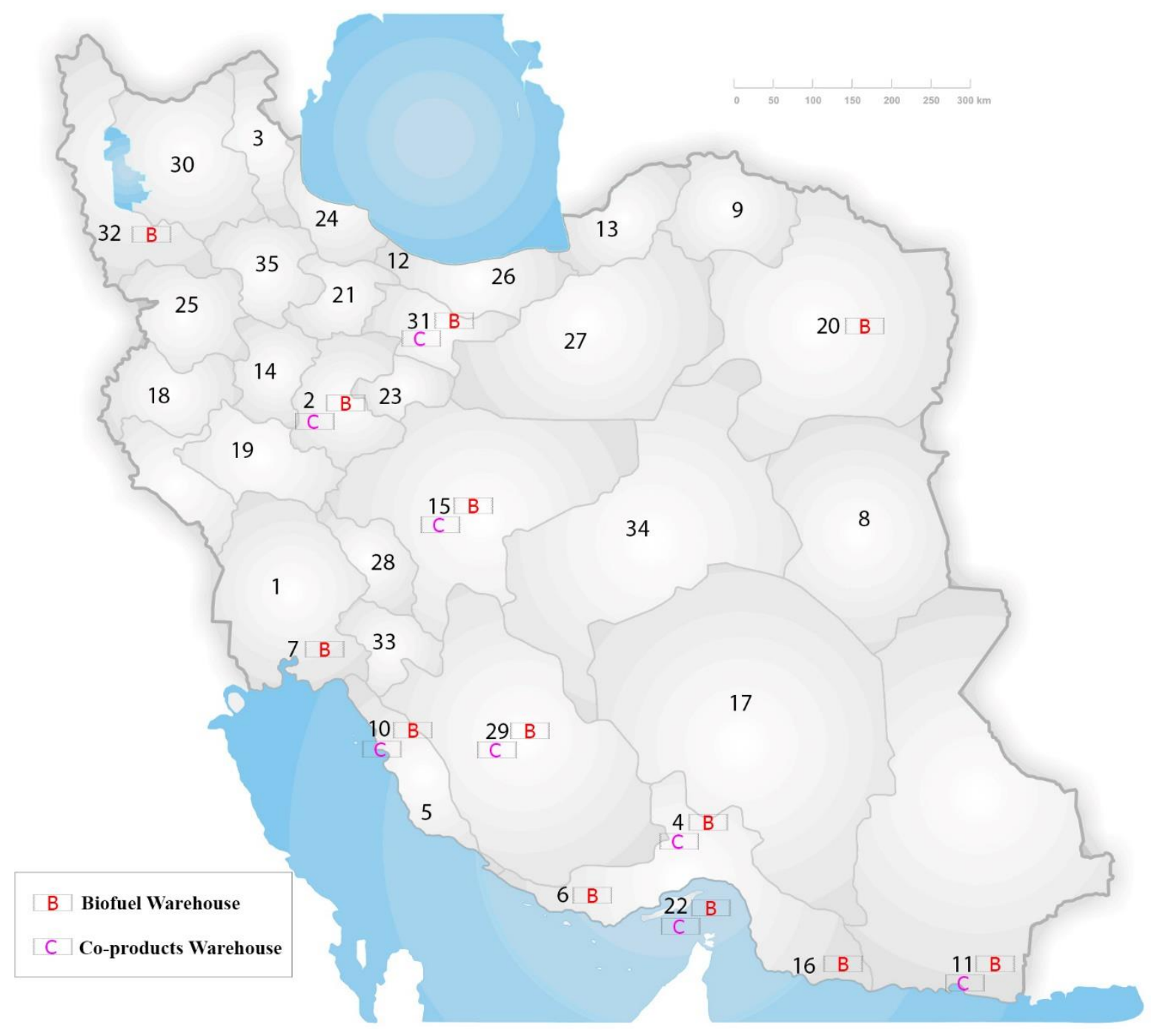

448

449 Fig. 7. Cities selected for constructing warehouses

450

451 Table 15. Biofuel customers

\begin{tabular}{llllll}
\hline No. & City & No. & City & No. & City \\
\hline 1 & Ahvaz & 17 & Kerman & 27 & Semnan \\
2 & Arak & 19 & Khorram abad & 29 & Shiraz \\
3 & Ardabil & 20 & Mashhad & 30 & Tabriz \\
4 & Bandar Abbas & 21 & Qazvin & 31 & Tehran \\
10 & Bushehr & 23 & Qom & 32 & Urmia
\end{tabular}


14 Hamedan

24

Rasht

34

15

Isfahan

26

Sari

35

Yazd

452

453

454 Table 16. Co-product customers

\begin{tabular}{llll}
\hline No. & City & No. & City \\
\hline 1 & Ahvaz & 24 & Rasht \\
2 & Arak & 29 & Shiraz \\
3 & Ardabil & 30 & Tabriz \\
4 & Bandar Abbas & 31 & Tehran \\
15 & Isfahan & 21 & Qazvin \\
20 & Mashhad & &
\end{tabular}

455

456 


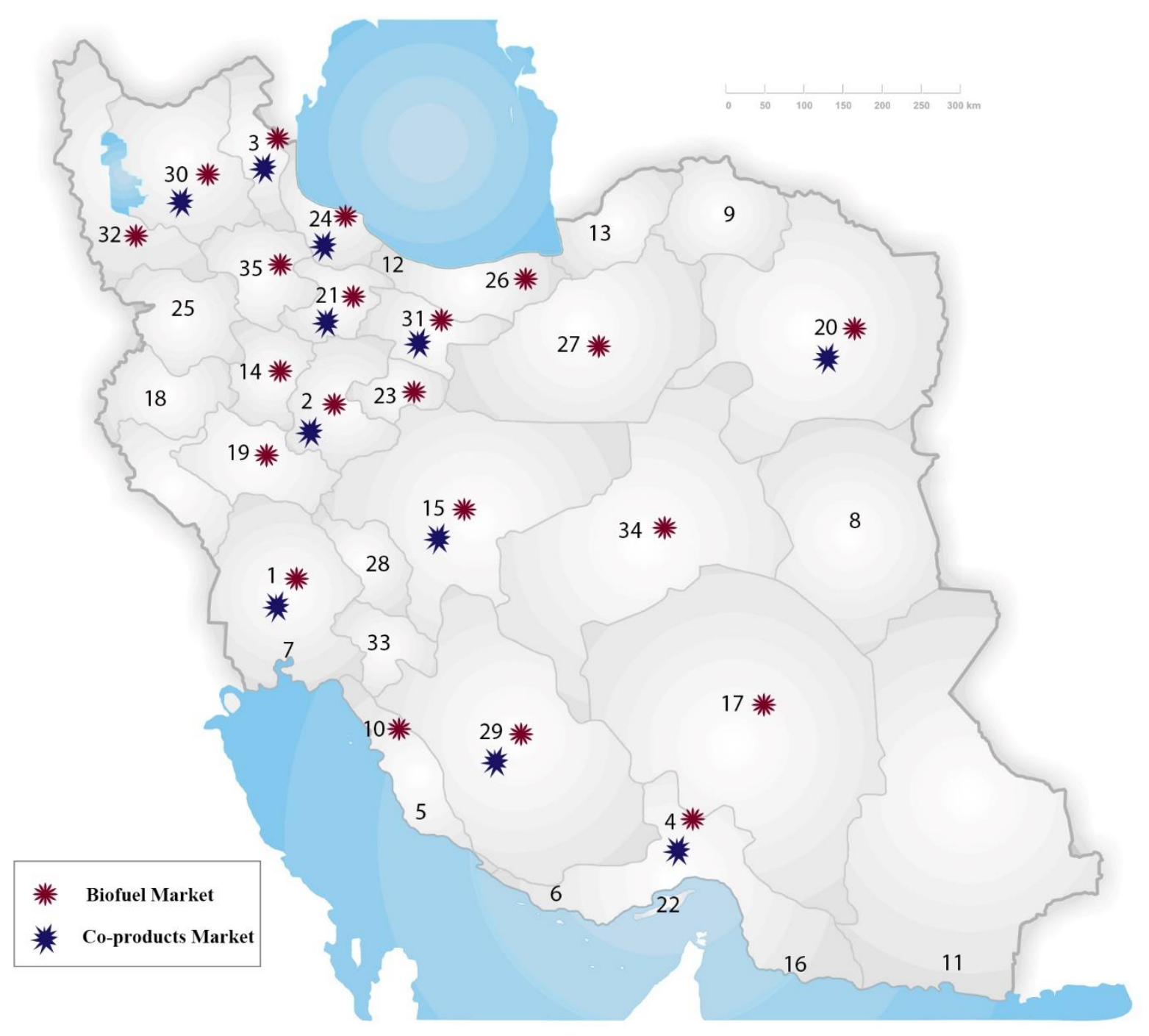

Fig. 8. Markets for the end products

460 The microalgae cultivation step has four types of costs including variable cost, fixed cost, operational cost, 461 and the cost for the delivery of feedstock to the cultivation location. The variable cost depends on the 462 quantity of the materials spent during the construction of the Open Pond and PBR, while the operational 463 cost is incurred only after the cultivation of microalgae is started in the Open Pond and PBR. The costs of 464 microalgae cultivation have an increasing trend in a 5-year planning horizon, while the fixed and 465 transportation costs are the highest expenses due to the far distance of the feedstock resources from the 466 microalgae cultivation facilities. The vast areas in the provinces of Iran are another factor for the high 467 transportation costs. Since the preprocessing of microalgae is carried out in the same location as the 468 microalgae cultivation, there would be no need to transport the cultivated microalgae to a preprocessing facility. The microalgae transportation cost is, thus, ignored in this step (Fig. 9). 


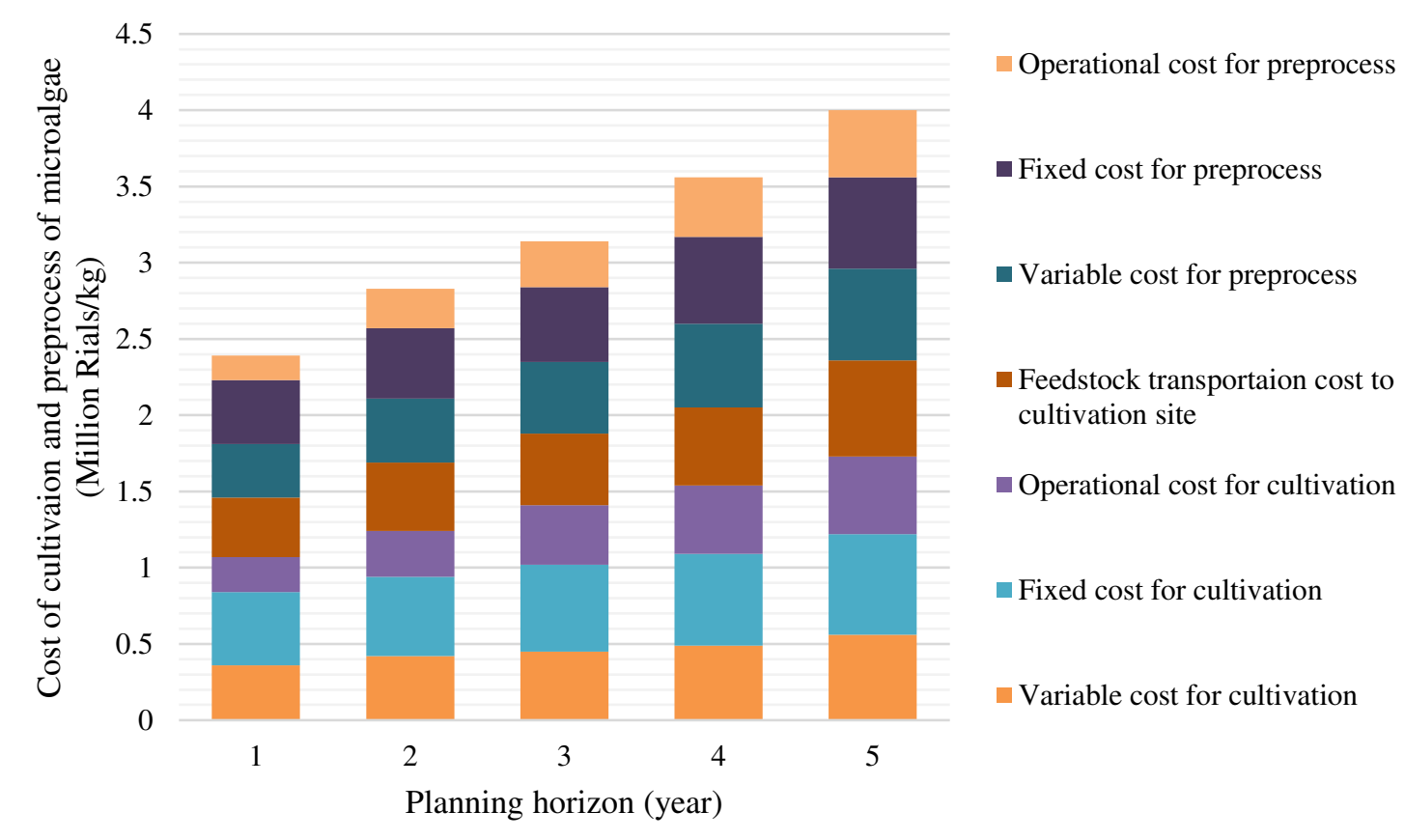

471 Fig. 9. Microalgae cultivation and the preprocessing costs

472

473 Fig. 10 shows the costs of producing biofuels and co-products. It is assumed that the refineries converting 474 the microalgae to biofuels and co-products have already been built. Consequently, the fixed and the 475 investment costs sharply decrease. Just like the previous steps of the supply chain, however, the variable 476 and the operational costs have an increasing trend. Since the distance between the preprocessing facilities 477 and the bio-refinery locations is long, the transportation costs increase. It should be noted that all the costs 478 have been calculated according to the average inflation rate of $13 \%$ in Iran. 


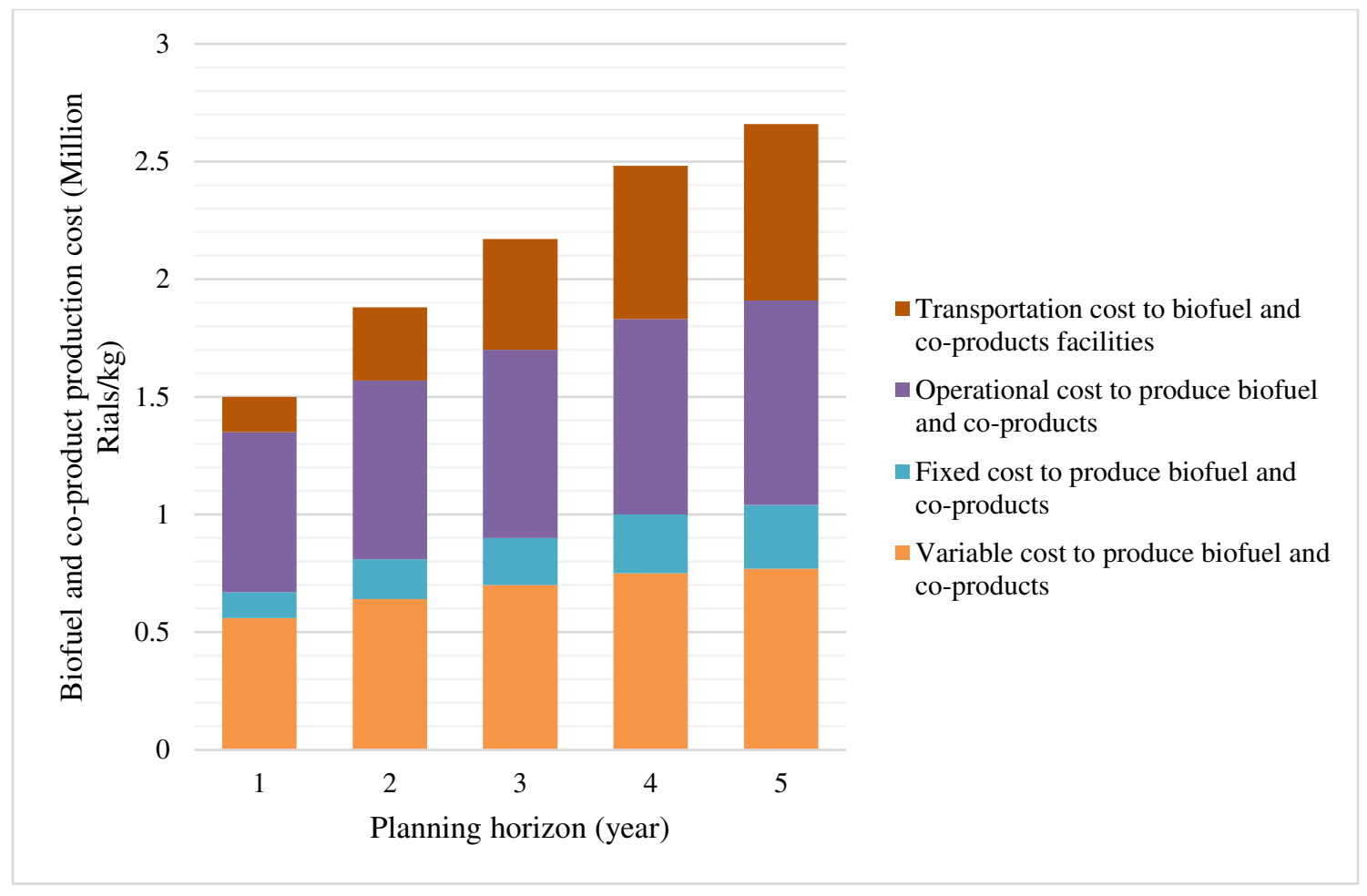

480 Fig.10. Costs of producing the biofuel and co-products

481 Fig. 11 reports the warehouse cost for biofuels and co-products. The cost of transportation from the biofuel and co-product refineries to the warehouses and that of transporting the end-products to the customer are also given. Here, the costs of the two transportation modes (i.e., truck and train) are evaluated too. Of different steps of the supply chain, the transportation of the end-products to the customers imposes the highest expenses. 


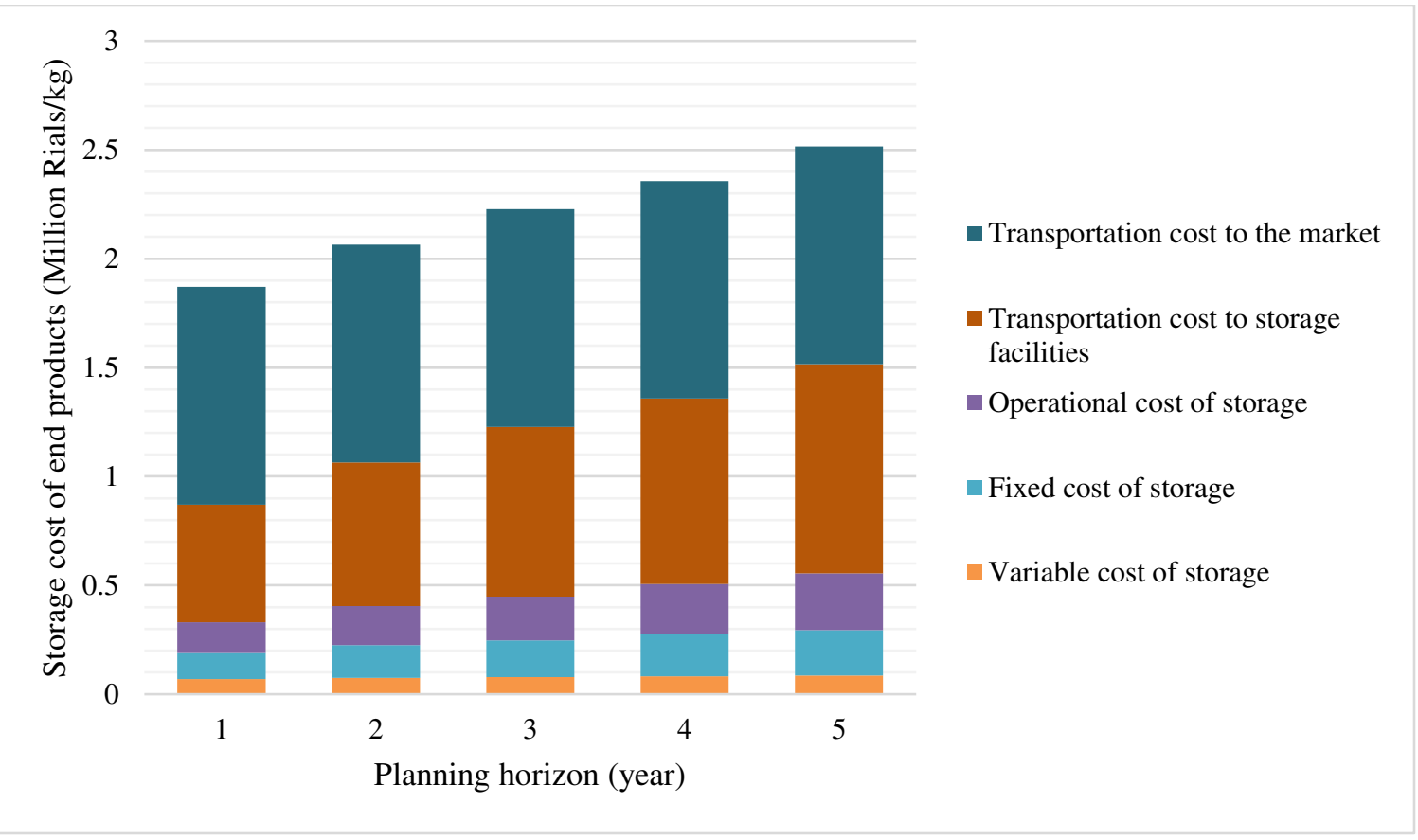

487 Fig. 11. Cost of storing the end products

\section{3.5. The amount of input fossil fuel}

490 Fig. 12 shows the amounts of the input fossil energy in all the steps of the MBCSCN with regard to the 491 corresponding technologies. As it can be seen, the largest amount of the input fossil energy belongs to the 492 transportation of the end-products to the customers and the biofuel production (Jian, Jing, \& Peidong, 2015; 493 Karimi, Naini, \& Sadjadi, 2021). 


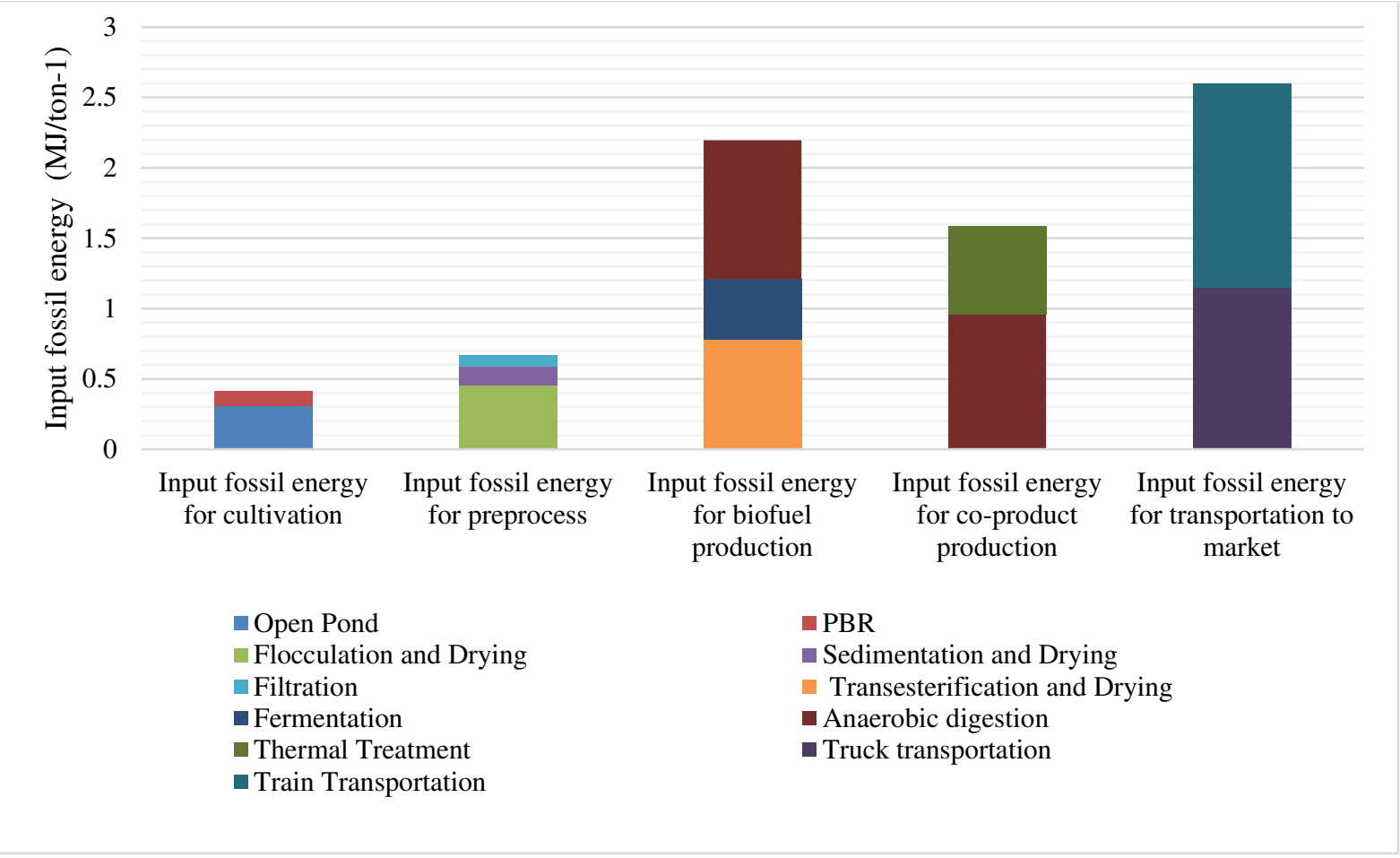

Fig. 12. Amount of consumed fossil energy

\section{3.6. Sensitivity analysis}

498 In order to measure the effectiveness and the applicability of the proposed model, it is necessary to study the influence of the critical parameters on it. In this study, the effects of the variation of three parameters on the total cost have been studied. The parameter are the feedstock, the biofuel and co-products transportation costs and the feedstock price. Furthermore, the rate of change for each parameter has been considered to be $\pm 15 \%$. The variation of each parameter and its effect on the total cost are presented in Fig. 


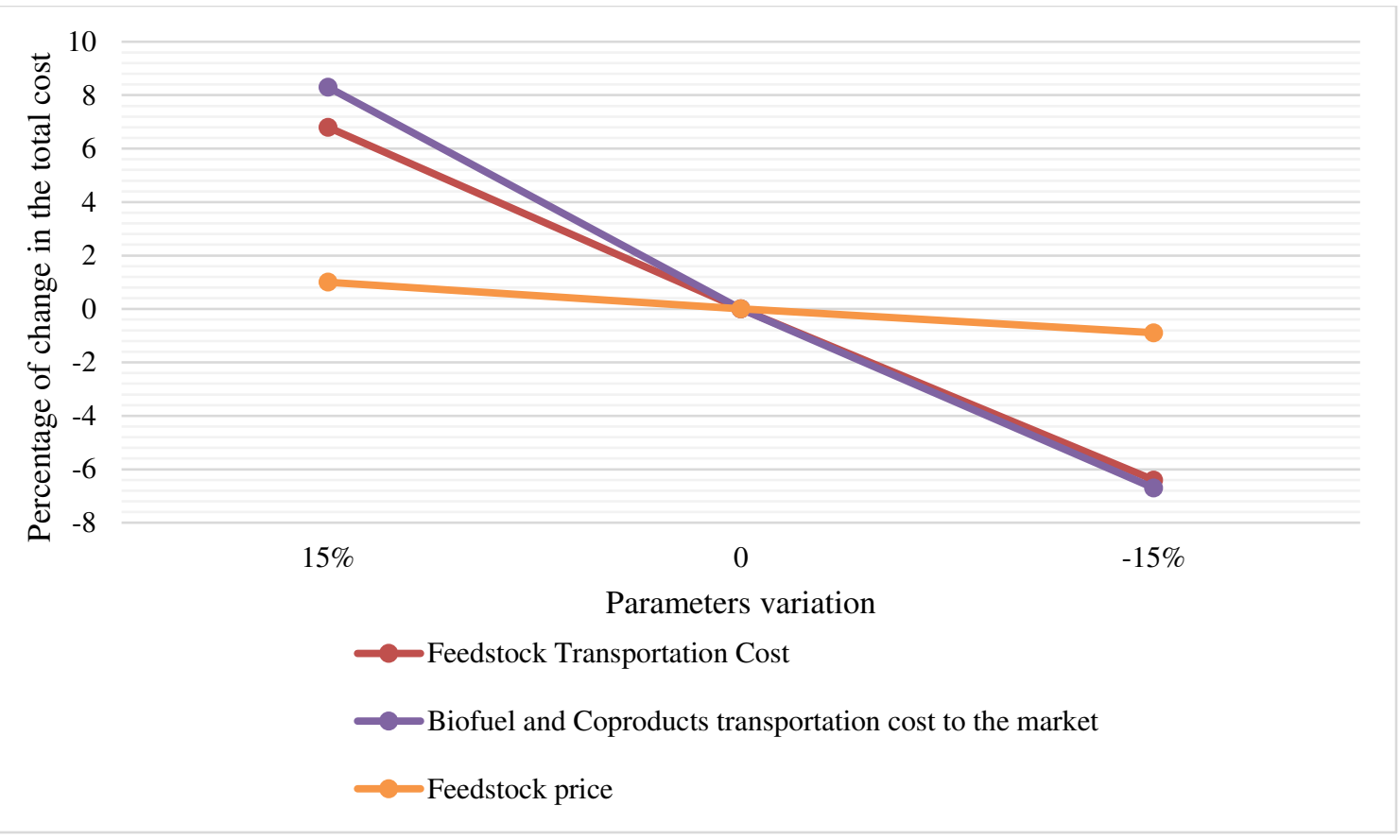

505

Fig. 13. Effects of the variations in the feedstock, biofuel and co-products transportation costs and the feedstock price on the total cost

It should be noted that, despite the fact that Iran is one of the largest producers of oil and petroleum products, its industry is significantly depending on transportation. Any changes in the transportation cost can lead to extreme price fluctuation. Therefore, this study has addressed the influence of the transportation cost on the total cost as an important issue. Fig. 13 illustrates the effects of the variation of three parameters on the total cost in one chart. Among all the parameters, the cost of transporting biofuel and co-product (end products) to the customer has had caused the greatest change in the total cost. Due to the vast area of the provinces and the long distance between the end products producers and the customer, more energy has to be consumed, which will cause more expenses. As the transportation cost of the end products increases by $15 \%$, the total cost increases for $8.3 \%$. If the cost of transporting the end products decreases by $15 \%$, the total cost will decrease by $6.7 \%$. The end products transportation is done by truck and train. Since the feedstock transportation is done by truck and train, the changes in its cost will be the same as those in the cost of the end product transportation. However, due to the shorter distance between the feedstock supply market and the cultivation locations, the expected transportation cost is lower than the cost of the end product transportation. Among all the parameters, feedstock prices have the minimum effects on the total cost. Since the feedstock price fluctuation is low and there are various feedstock suppliers with competitive prices, the total cost will have no significant change.

\section{Conclusion}


526 In this study, a two-stage framework was proposed to optimize the designed MBCSCN. In the first stage, 527 the locations selected for microalgae cultivation were identified based on the AHP method. In the second 528 stage, a deterministic multi-period, multi-objective MILP model was developed with an objective function

529 of two criteria including economy and environmental impacts. The model was solved using the $\varepsilon$-constraint 530 method. Then, a case study was conducted to specify the effectiveness and the optimality of the model. 531 Based on the results obtained in the first stage, 10 cities were identified and selected as locations for 532 microalgae cultivation in Iran. The model was also implemented to determine appropriate microalgae 533 species, the required quantity of the feedstock, a feedstock supply location, a preprocessing location, a 534 location for biofuel and co-product production, the production capacity, the type of the biofuel and co535 product to produce, the required technology, and the transportation modes in each step of the supply chain. 536 This model aims at evaluating the breakeven points of two objective functions including the maximization 537 of profit and the minimization of the environmental impacts of fossil fuel consumption. The results of the 538 study indicate that the cost of producing biofuels should compete with the cost of producing fossil fuels in 539 Iran. The main reason for the lack of competition is the reduction of oil prices, as a competing factor, in 540 recent years. Another finding of this study regards the large share of transportation costs in the total costs 541 of supply chains. Hence, there are certain issues to recommend for future studies. They can consider 542 uncertainty in the price of biofuels and co-products, concentrate more on the production and distribution of 543 microalgae-based co-products, and find ways to reduce the transportation costs in microalgae-based biofuel 544 supply chains. 


\section{Declarations}

547 Ethics approval:

548 - Not applicable.

549 Consent to participate:

550 - Not applicable.

551 Consent for publication:

552 - Not applicable

553 Availability of data and materials:

554 - All data generated or analyzed during this study are included in this published article.

555 Competing Interests:

556 - Not applicable.

557 Funding:

558 - No funds, grants, or other support was received.

559 - The authors have no relevant financial or non-financial interests to disclose.

Authors' contributions:

561

562

563

564

565

566

567
- Study conception and design, data collection, analysis and writing the first draft of the manuscript were performed by Mohammad Ehsan Zerafati. Validation of data and verification of research outputs were performed by Ali Bozorgi-Amiri. Critical review, commentary and revision of translation were performed by Amir Mohammad GolMohammadi. Fariborz Jolai commented on final version of the manuscript. All authors read and approved the final manuscript. 


\section{References}

Abraham, A., \& Jain, L. (2005). Evolutionary multiobjective optimization. In Evolutionary Multiobjective Optimization (pp. 1-6): Springer.

Adeniyi, O. M., Azimov, U., \& Burluka, A. (2018). Algae biofuel: Current status and future applications. Renewable and Sustainable Energy Reviews, 90, 316-335.

Adenle, A. A., Haslam, G. E., \& Lee, L. (2013). Global assessment of research and development for algae biofuel production and its potential role for sustainable development in developing countries. Energy Policy, 61, 182-195.

Ahn, Y.-C., Lee, I.-B., Lee, K.-H., \& Han, J.-H. (2015). Strategic planning design of microalgae biomass-tobiodiesel supply chain network: Multi-period deterministic model. Applied Energy, 154, 528-542.

Akbarian-Saravi, N., Mobini, M., \& Rabbani, M. (2020). Development of a comprehensive decision support tool for strategic and tactical planning of a sustainable bioethanol supply chain: Real case study, discussions and policy implications. Journal of Cleaner Production, 244, 118871.

Akgul, O., Shah, N., \& Papageorgiou, L. G. (2012). An optimisation framework for a hybrid first/second generation bioethanol supply chain. Computers \& Chemical Engineering, 42, 101-114.

Aliyu, A., Lee, J., \& Harvey, A. (2021). Microalgae for biofuels via thermochemical conversion processes: A review of cultivation, harvesting and drying processes, and the associated opportunities for integrated production. Bioresource Technology Reports, 100676.

An, H., Wilhelm, W. E., \& Searcy, S. W. (2011). A mathematical model to design a lignocellulosic biofuel supply chain system with a case study based on a region in Central Texas. Bioresource technology, 102(17), 7860-7870.

Andrade, D. S., Telles, T. S., \& Castro, G. H. L. (2020). The Brazilian microalgae production chain and alternatives for its consolidation. Journal of Cleaner Production, 250, 119526.

Arabi, M., Yaghoubi, S., \& Tajik, J. (2019a). Algal biofuel supply chain network design with variable demand under alternative fuel price uncertainty: A case study. Computers \& Chemical Engineering, 130, 106528.

Arabi, M., Yaghoubi, S., \& Tajik, J. (2019b). A mathematical model for microalgae-based biobutanol supply chain network design under harvesting and drying uncertainties. Energy, 179, 1004-1016.

Asadi, E., Habibi, F., Nickel, S., \& Sahebi, H. (2018). A bi-objective stochastic location-inventory-routing model for microalgae-based biofuel supply chain. Applied Energy, 228, 2235-2261.

Babazadeh, R., Ghaderi, H., \& Pishvaee, M. S. (2019). A benders-local branching algorithm for secondgeneration biodiesel supply chain network design under epistemic uncertainty. Computers \& Chemical Engineering, 124, 364-380.

Babazadeh, R., Razmi, J., Rabbani, M., \& Pishvaee, M. S. (2015). An integrated data envelopment analysismathematical programming approach to strategic biodiesel supply chain network design problem. Journal of Cleaner Production.

Bahadar, A., \& Khan, M. B. (2013). Progress in energy from microalgae: a review. Renewable and Sustainable Energy Reviews, 27, 128-148.

Bai, Y., Ouyang, Y., \& Pang, J.-S. (2012). Biofuel supply chain design under competitive agricultural land use and feedstock market equilibrium. Energy Economics, 34(5), 1623-1633.

Balaman, Ş. Y., \& Selim, H. (2014). A network design model for biomass to energy supply chains with anaerobic digestion systems. Applied Energy, 130, 289-304.

Barros, A. I., Gonçalves, A. L., Simões, M., \& Pires, J. C. (2015). Harvesting techniques applied to microalgae: A review. Renewable and Sustainable Energy Reviews, 41, 1489-1500.

Barry, A., Wolfe, A., English, C., Ruddick, C., \& Lambert, D. (2016). 2016 National Algal Biofuels Technology Review. Retrieved from 
Beiki, H., Seyedhosseini, S. M., Mihardjo, L. W., \& Seyedaliakbar, S. M. (2021). Multiobjective locationrouting problem of relief commodities with reliability. Environmental Science and Pollution Research, 1-10.

Branke, J., Deb, K., Miettinen, K., \& Slowiński, R. (2008). Multiobjective optimization: Interactive and evolutionary approaches (Vol. 5252): Springer.

Branyikova, I., Prochazkova, G., Potocar, T., Jezkova, Z., \& Branyik, T. (2018). Harvesting of microalgae by flocculation. Fermentation, 4(4), 93.

Chen, G., Zhao, L., \& Qi, Y. (2015). Enhancing the productivity of microalgae cultivated in wastewater toward biofuel production: A critical review. Applied Energy, 137, 282-291.

Chisti, Y. (2013). Constraints to commercialization of algal fuels. Journal of biotechnology, 167(3), 201214.

Chu, R., Li, S., Zhu, L., Yin, Z., Hu, D., Liu, C., \& Mo, F. (2021). A review on co-cultivation of microalgae with filamentous fungi: Efficient harvesting, wastewater treatment and biofuel production. Renewable and sustainable energy reviews, 139, 110689.

Coleman, A. M., Abodeely, J. M., Skaggs, R. L., Moeglein, W. A., Newby, D. T., Venteris, E. R., \& Wigmosta, M. S. (2014). An integrated assessment of location-dependent scaling for microalgae biofuel production facilities. Algal Research, 5, 79-94.

Davis, R., Aden, A., \& Pienkos, P. T. (2011). Techno-economic analysis of autotrophic microalgae for fuel production. Applied Energy, 88(10), 3524-3531.

Efroymson, R. A., Jager, H. I., Mandal, S., Parish, E. S., \& Mathews, T. J. (2020). Better Management Practices for Environmentally Sustainable Production of Microalgae and Algal Biofuels. Journal of Cleaner Production, 125150.

Fallahpour, A., Nayeri, S., Sheikhalishahi, M., Wong, K. Y., Tian, G., \& Fathollahi-Fard, A. M. (2021). A hyperhybrid fuzzy decision-making framework for the sustainable-resilient supplier selection problem: a case study of Malaysian Palm oil industry. Environmental Science and Pollution Research, 1-21.

Fathollahi-Fard, A. M., Ahmadi, A., \& Al-e-Hashem, S. M. (2020). Sustainable closed-loop supply chain network for an integrated water supply and wastewater collection system under uncertainty. Journal of Environmental Management, 275, 111277.

Ghaderi, H., Moini, A., \& Pishvaee, M. S. (2018). A multi-objective robust possibilistic programming approach to sustainable switchgrass-based bioethanol supply chain network design. Journal of Cleaner Production, 179, 368-406.

Ghosh, T., \& Bakshi, B. R. (2019). Designing biofuel supply chains while mitigating harmful algal blooms with treatment wetlands. Computers \& Chemical Engineering, 126, 113-127.

Golmohammadi, A.-M., Honarvar, M., Hosseini-Nasab, H., \& Tavakkoli-Moghaddam, R. (2020). A biobjective Optimization Model for a Dynamic Cell Formation Integrated with Machine and Cell Layouts in a Fuzzy Environment. Fuzzy Information and Engineering, 1-19.

Gong, J., \& You, F. (2015). An efficient global optimization algorithm for mixed-integer nonlinear fractional programs with separable concave terms. Paper presented at the American Control Conference (ACC), 2015.

Gutiérrez-Arriaga, C. G., Serna-González, M., Ponce-Ortega, J. M., \& El-Halwagi, M. M. (2014). Sustainable integration of algal biodiesel production with steam electric power plants for greenhouse gas mitigation. ACS Sustainable Chemistry \& Engineering, 2(6), 1388-1403.

Hadian, H., Chahardoli, S., Golmohammadi, A.-M., \& Mostafaeipour, A. (2020). A practical framework for supplier selection decisions with an application to the automotive sector. International Journal of Production Research, 58(10), 2997-3014.

Hosseinalizadeh, R., Khamseh, A. A., \& Akhlaghi, M. M. (2019). A multi-objective and multi-period model to design a strategic development program for biodiesel fuels. Sustainable Energy Technologies and Assessments, 36, 100545. 
Idrees, M. (2014). Making biofuels from microalgae-A review of technologies. Journal of Food Science and Technology, 1(2), 007-014.

Ismail, M. M., Ismail, G. A., \& El-Sheekh, M. M. (2020). Potential assessment of some micro-and macroalgal species for bioethanol and biodiesel production. Energy Sources, Part A: Recovery, Utilization, and Environmental Effects, 1-17.

Jian, H., Jing, Y., \& Peidong, Z. (2015). Life Cycle Analysis on Fossil Energy Ratio of Algal Biodiesel: Effects of Nitrogen Deficiency and Oil Extraction Technology. The Scientific World Journal, 2015.

Karimi, S. K., Naini, S. G. J., \& Sadjadi, S. J. (2021). An integration of environmental awareness into flexible supply chains: a trade-off between costs and environmental pollution. Environmental Science and Pollution Research, 1-11.

Kim, J., Yoo, G., Lee, H., Lim, J., Kim, K., Kim, C. W., . . Y Yang, J.-W. (2013). Methods of downstream processing for the production of biodiesel from microalgae. Biotechnology advances, 31(6), 862876.

Li, Z., Xie, C., Peng, P., Gao, X., \& Wan, Q. (2021). Multi-objective location-scale optimization model and solution methods for large-scale emergency rescue resources. Environmental Science and Pollution Research, 1-14.

Mahjoub, N., Sahebi, H., Mazdeh, M., \& Teymouri, A. (2020). Optimal design of the second and third generation biofuel supply network by a multi-objective model. Journal of Cleaner Production, 256, 120355.

Mata, T. M., Martins, A. A., \& Caetano, N. S. (2010). Microalgae for biodiesel production and other applications: a review. Renewable and sustainable energy reviews, 14(1), 217-232.

Mavrotas, G. (2009). Effective implementation of the $\varepsilon$-constraint method in multi-objective mathematical programming problems. Applied mathematics and computation, 213(2), 455-465.

Mohseni, S., Pishvaee, M. S., \& Sahebi, H. (2016). Robust design and planning of microalgae biomass-tobiodiesel supply chain: A case study in Iran. Energy, 111, 736-755.

Mohtashami, Z., Aghsami, A., \& Jolai, F. (2020). A green closed loop supply chain design using queuing system for reducing environmental impact and energy consumption. Journal of Cleaner Production, 242, 118452.

Mohtashami, Z., Bozorgi-Amiri, A., \& Tavakkoli-Moghaddam, R. (2021). A two-stage multi-objective second generation biodiesel supply chain design considering social sustainability: A case study. Energy, 121020.

Mojtahedi, M., Fathollahi-Fard, A. M., Tavakkoli-Moghaddam, R., \& Newton, S. (2021). Sustainable vehicle routing problem for coordinated solid waste management. Journal of Industrial Information Integration, 23, 100220.

Najafi, G., Ghobadian, B., \& Yusaf, T. F. (2011). Algae as a sustainable energy source for biofuel production in Iran: A case study. Renewable and Sustainable Energy Reviews, 15(8), 3870-3876.

Nasr, N., Niaki, S. T. A., Kashan, A. H., \& Seifbarghy, M. (2021). An efficient solution method for an agrifresh food supply chain: hybridization of Lagrangian relaxation and genetic algorithm. Environmental Science and Pollution Research, 1-19.

Pahlevan, S. M., Hosseini, S. M. S., \& Goli, A. (2021). Sustainable supply chain network design using products' life cycle in the aluminum industry. Environmental Science and Pollution Research, 1-25.

Parsaeifar, S., Bozorgi-Amiri, A., Naimi-Sadigh, A., \& Sangari, M. S. (2019). A game theoretical for coordination of pricing, recycling, and green product decisions in the supply chain. Journal of Cleaner Production, 226, 37-49.

Pokoo-Aikins, G., Nadim, A., El-Halwagi, M. M., \& Mahalec, V. (2010). Design and analysis of biodiesel production from algae grown through carbon sequestration. Clean Technologies and Environmental Policy, 12(3), 239-254. 
Quinn, J. C., \& Davis, R. (2015). The potentials and challenges of algae based biofuels: A review of the techno-economic, life cycle, and resource assessment modeling. Bioresource technology, 184, 444-452.

Rabbani, M., Momen, S., Akbarian-Saravi, N., Farrokhi-Asl, H., \& Ghelichi, Z. (2020). Optimal design for sustainable bioethanol supply chain considering the bioethanol production strategies: A case study. Computers \& Chemical Engineering, 134, 106720.

Rahemi, H., Torabi, S. A., Avami, A., \& Jolai, F. (2020). Bioethanol supply chain network design considering land characteristics. Renewable and Sustainable Energy Reviews, 119, 109517.

Rizwan, M., Lee, J. H., \& Gani, R. (2013). Optimal processing pathway for the production of biodiesel from microalgal biomass: a superstructure based approach. Computers \& Chemical Engineering, 58, 305-314.

Salomon, V. (2018). Multi-Criteria Methods and Techniques Applied to Supply Chain Management: BoDBooks on Demand.

Shabbir, M. S., Mahmood, A., Setiawan, R., Nasirin, C., Rusdiyanto, R., Gazali, G., . . Batool, F. (2021). Closed-loop supply chain network design with sustainability and resiliency criteria. Environmental Science and Pollution Research, 1-16.

Sharma, B., Brandes, E., Khanchi, A., Birrell, S., Heaton, E., \& Miguez, F. (2015). Evaluation of Microalgae Biofuel Production Potential and Cultivation Sites Using Geographic Information Systems: A Review. BioEnergy Research, 8(4), 1714-1734.

Shi, R., Handler, R. M., \& Shonnard, D. R. (2019). Life cycle assessment of novel technologies for algae harvesting and oil extraction in the renewable diesel pathway. Algal Research, 37, 248-259.

Slade, R., \& Bauen, A. (2013). Micro-algae cultivation for biofuels: cost, energy balance, environmental impacts and future prospects. Biomass and Bioenergy, 53, 29-38.

Tzeng, G.-H., \& Huang, J.-J. (2011). Multiple attribute decision making: methods and applications: CRC press.

Van Boxtel, A., Perez-Lopez, P., Breitmayer, E., \& Slegers, P. (2015). The potential of optimized process design to advance LCA performance of algae production systems. Applied Energy, 154, 1122-1127.

Zhang, K., Zhang, F., \& Wu, Y.-R. (2021). Emerging technologies for conversion of sustainable algal biomass into value-added products: A state-of-the-art review. Science of The Total Environment, 147024.

Zhang, L. (2013). Biofuel supply chain and bottom-up market equilibrium model for production and policy analysis.

Zhou, W., Chen, P., Min, M., Ma, X., Wang, J., Griffith, R., . . Li, Y. (2014). Environment-enhancing algal biofuel production using wastewaters. Renewable and Sustainable Energy Reviews, 36, 256-269. 


\section{Supplementary Files}

This is a list of supplementary files associated with this preprint. Click to download.

- Responsetoeditorcomments.docx 